\title{
Mesenchymal stem cell as a novel approach to systemic sclerosis; current status and future perspectives
}

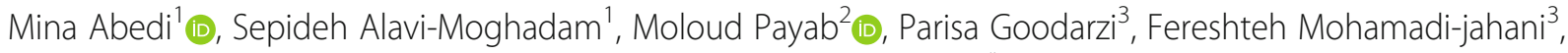 \\ Forough Azam Sayahpour ${ }^{4}$, Bagher Larijani ${ }^{5}$ (D) and Babak Arjmand ${ }^{1,2^{*}}$ (D)
}

\begin{abstract}
Systemic sclerosis is a rare chronic autoimmune disease with extensive microvascular injury, damage of endothelial cells, activation of immune responses, and progression of tissue fibrosis in the skin and various internal organs. According to epidemiological data, women's populations are more susceptible to systemic sclerosis than men. Until now, various therapeutic options are employed to manage the symptoms of the disease. Since stem cell-based treatments have developed as a novel approach to rescue from several autoimmune diseases, it seems that stem cells, especially mesenchymal stem cells as a powerful regenerative tool can also be advantageous for systemic sclerosis treatment via their remarkable properties including immunomodulatory and anti-fibrotic effects. Accordingly, we discuss the contemporary status and future perspectives of mesenchymal stem cell transplantation for systemic sclerosis.
\end{abstract}

Keywords: Anti- fibrotic effect, Autoimmune disease, Cell therapy, Immunomodulation, Mesenchymal stem cells, Regenerative medicine, Systemic sclerosis

\section{Background}

Systemic sclerosis (SSc) or scleroderma as a rare heterogeneous and chronic autoimmune disease (characterized by extensive microvascular injury, damage of endothelial cells (ECs), activation of immune responses, and progression of tissue fibrosis) can affect the skin and various internal organs including the heart, lungs, kidneys, and gastrointestinal tract (Sobolewski et al. 2019a; Asano 2018; Sticherling 2012; Pattanaik et al. 2015). Of course, cutaneous manifestations (skin thickening and sclerotic skin lesions) are among the main and primary hallmarks of SSc

\footnotetext{
* Correspondence: barjmand@sina.tums.ac.ir

${ }^{1}$ Cell Therapy and Regenerative Medicine Research Center, Endocrinology and Metabolism Molecular-Cellular Sciences Institute, Tehran University of Medical Sciences, Tehran, Iran

${ }^{2}$ Metabolomics and Genomics Research Center, Endocrinology and

Metabolism Molecular-Cellular Sciences Institute, Tehran University of Medical Sciences, Tehran, Iran

Full list of author information is available at the end of the article
}

(Krieg and Takehara 2009; Krieg and Takehara 2006). Generally, age, gender, and race as pivotal factors can determine SSc susceptibility. In this respect, females are more susceptible to SSc than males and the most prevalent age of involvement is 30-50years (Mayes 2003; Nikpour et al. 2010). The subtype of the SSc, the disease stage, and the type of involved organs are crucial elements to determine the best approach for treatment, as well as the most appropriate course of treatment (Sobolewski et al. 2019b; Bissell et al. 2017). Herein, various therapeutic options are offered to control and manage the SSc symptoms. Collectively, mentioned therapeutic options include chemical drugs (prescribed based on the affected organs such as steroid drugs, immune system regulators, and gastrointestinal medications), moisturizers (herbal and/or chemical), phototherapy (especially the use of UVA-1 light to treat skin thickening and lesions), exercise, physical therapy, and occupational therapy (Adnan 2008;

\section{Springer Open}

(c) The Author(s). 2020 Open Access This article is licensed under a Creative Commons Attribution 4.0 International License, which permits use, sharing, adaptation, distribution and reproduction in any medium or format, as long as you give appropriate credit to the original author(s) and the source, provide a link to the Creative Commons licence, and indicate if changes were made. The images or other third party material in this article are included in the article's Creative Commons licence, unless indicated otherwise in a credit line to the material. If material is not included in the article's Creative Commons licence and your intended use is not permitted by statutory regulation or exceeds the permitted use, you will need to obtain permission directly from the copyright holder. To view a copy of this licence, visit http://creativecommons.org/licenses/by/4.0/. The Creative Commons Public Domain Dedication waiver (http://creativecommons.org/publicdomain/zero/1.0/) applies to the data made available in this article, unless otherwise stated in a credit line to the data. 
Sapadin and Fleischmajer 2002). Moreover, in recent decades, several cell-based therapies and regenerative medicine approaches (as promising and novel alternative options) have studied for SSc and many other chronic diseases (Song et al. 2017; Zakrzewski et al. 2019; Goodarzi et al. 2015; Goodarzi et al. 2014; Payab et al. 2018; Soleimani et al. 2016). In other words, stem cell transplantation has developed as a new way to salvation from different life-threatening autoimmune diseases. Indeed, cell therapy can be effective by preventing the abnormal functioning of self-activated immune cells with the help of safe and effective immune tolerance formed by transplanted cells (Rosa et al. 2007; Resnick et al. 2017; Del Papa et al. 2018; Dazzi et al. 2007; Radbruch and Thiel 2004). Among the various cells, mesenchymal stem cells (MSCs) (obtained from diverse tissues) are mostly known as perfect agents to the regenerative objects to represent cell multi-potency along with anti-inflammatory and powerful regenerating qualities (Larijani et al. 2015; Han et al. 2019; Pittenger et al. 2019; Goodarzi et al. 2018a; Goodarzi et al. 2019a). Furthermore, a broad range of in vitro and in vivo preclinical investigations have shown that autologous and allogeneic MSCs can be employed in a variety of immunemediated statuses (Zhao et al. 2016; Figueroa et al. 2012). Hence, in the current review, we discuss the contemporary status and future perspectives of MSCs - based therapeutic approaches for systemic sclerosis as an immunemediated condition.

\section{A review of scleroderma symptoms and pathophysiology}

SSc is an autoimmune disease with a prevalence of 100 to 300 per million depending on the country. Furthermore, it is a disabling disease that affects the quality of life (Maria et al. 2016a; Rozier et al. 2018) by causing symptoms like loss of hand function, pain, and psychological problems. It also reduces life expectancy by causing death from SSc-related complications and raising the incidence of malignancy and cardiovascular problems (Rozier et al. 2018; Elhai et al. 2017; Poudel et al. 2018; Zeineddine et al. 2016). In rapidly progressive forms of the disease, the five-year mortality rate can reach 30$50 \%$ depending on the extent of skin, cardiopulmonary, and renal involvement (van Laar and Sullivan 2013; Velier et al. 2019). Vasculopathy)which can make one of the earliest symptoms of the disease(, Raynaud's Phenomenon (happen as well as digital ulcers), pulmonary arterial hypertension, and telangiectasia (Rozier et al. 2018; Velier et al. 2019; Desbois and Cacoub 2016) are associated with SSc. The main characteristic of the disease is the collagen accumulation in the skin and internal organs, especially the lungs, but the involvement of the heart and digestive system is also reported (Maria et al. 2016a; Rozier et al. 2018; Velier et al. 2019;
Chighizola et al. 2011; Okamura et al. 2020). As mentioned, there are three main axes which cause the symptoms: autoimmunity, vascular abnormality, and fibrosis (Asano 2018; Maria et al. 2016a; Rozier et al. 2018; Okamura et al. 2020). Additionally, it has been demonstrated that the environment is involved in the pathophysiology of the disease (i.e., oxidative stress) (Rozier et al. 2018). Different types of antibodies are detected in more than $90 \%$ of the patients, including anti-DNA topoisomerase I, anti-RNA polymerase, and anticentromere antibodies (Okamura et al. 2020). These antibodies can cause immune system dysregulation and inflammation. This evidence is supported by the elevated levels of advanced oxidation protein products (AOPPs) in sera and decreased total antioxidant capacity in hypochlorous acid ( $\mathrm{HOCl})$-Induced mouse model of SSc which are a reflection of the inflammation level in the body (Maria et al. 2016a). Collagen retention and following tissue fibrosis can be considered as a key feature of SSc. Therein, fibrosis can form in the skin, lung, or other internal organs. Skin fibrosis can cause symptoms like cutaneous wounds (Sobolewski et al. 2019a; Rubio et al. 2018), degeneration of skin appendages such as hair follicles, sweat glands and cutaneous blood vessels (Wei et al. 2011), microstomia, xerostomia (Sobolewski et al. 2019a). Moreover, perivascular inflammatory cell infiltrates ( $\mathrm{T}$ lymphocytes and monocytes) as well as increased numbers of alpha-smooth muscle actin $(\alpha$ SMA)-positive myofibroblasts lead to skin atrophy (Sobolewski et al. 2019a; Wei et al. 2011). On the other hand, the main histological lesion of SSc in the lung is nonspecific interstitial pneumonitis (NSIP) that is a result of interstitial inflammation (in the form of patchy infiltration of the alveolar walls with lymphocytes, plasma cells, macrophages and eosinophils into the alveolar walls and a T helper 2 (Th2) positive bronchoalveolar lavage (BAL)test) along with fibrosis spreading (Wei et al. 2011). Another worse prognosis lesion is usual interstitial pneumonia (UIP) that is characterized by patchy fibrosis (Wei et al. 2011). Air space obliteration and honeycombing can be presented as a result of progressive thickening of the alveolar septa (Wei et al. 2011). Among other internal organs, the esophagus is almost always implicated (Sobolewski et al. 2019a; Wei et al. 2011). Concerning renal implications, vascular lesions are common in contrast to glomerulonephritis (Wei et al. 2011). Interstitial and perivascular fibrosis in cardiac tissue may be silent (Sobolewski et al. 2019a) or presented with diastolic dysfunction (Wei et al. 2011). Among several pro-fibrotic microRNAs (miRs), studies have shown that miR-199-3p is increased in the lung, kidney and liver and induces fibrosis as one of the major symptoms of SSc (Rubio et al. 2018; Cardenas et al. 2013). Indeed, miRs are major regulators of gene 
expression, the same process exists in pro-fibrotic pathways (Rubio et al. 2018; Bowen et al. 2013). Moreover, it is reported that miR-199-3p impairs cutaneous wound healing responses (Rubio et al. 2018; Chan et al. 2012). Caveolin-1 (CAV-1) is the confirmed target of miR-199$3 p$ and plays an important role in sequestering growth factor receptors and blocking their signaling from the plasma membrane (Rubio et al. 2018; Cardenas et al. 2013). Studies have reported that the CAV-1 level is reduced in fibrotic skin and lung diseases (Rubio et al. 2018; Castello-Cros et al. 2011). On the other hand, the phosphorylation of protein kinase B (PKB) or Akt (involved in cell metabolism, growth, proliferation, and survival) is increased during the fibrogenesis process of SSc (Rubio et al. 2018; Mercer et al. 2016; Zhang et al. 2016). Further, PKB is the other impaired pathway in the pathophysiology of scleroderma that is involved in increased levels of cell apoptosis. Increased level of apoptosis markers (such as caspase-9) reflects this evidence (Tashiro et al. 2015). Altogether, the main pathophysiology of the disease can be summarized in Fig. 1 (Velier et al. 2019).There are two main types of systemic sclerosis based on the extent of collagen deposition: diffuse form and the limited one. There is an extensive amount of fibrosis in the diffuse form of the disease, whereas in the limited form, some local points of fibrosis are detected (Rozier et al. 2018; Okamura et al. 2020; LeROY and Medsger Jr 2001). Generally, the pathophysiology of scleroderma types has not been completely understood to the date (Velier et al. 2019; Okamura et al. 2020). However, it has been believed that immune cells and their secretions play an important role in developing the disease (Okamura et al. 2020). In this context, Th2 cytokines, including interleukin (IL)-4, IL-6, and IL-13 are elevated in the patient's serum which promote fibrosis (Okamura et al. 2020; Hasegawa et al. 1998). In addition, IL-6 (from B cells) is involved in the disease pathogenesis (Okamura et al. 2020; Le Huu et al. 2012; Matsushita et al. 2018). Collectively, current therapeutic methods for SSc are symptomatic treatments which can't prevent the disease progression as well as curing the fibrosis lesions (Velier et al. 2019). Up to now, the only treatment that can have profits in the severe form of the disease is autologous hematopoietic stem cell transplantation. However, it can be accompanied by high toxicity, as a side effect (Velier et al. 2019; van Laar et al. 2014; Burt and Farge 2018; Sullivan et al. 2018). Hence, providing an appropriate and novel treatment for SSc seems to be necessary (Rozier et al. 2018; Uji et al. 2015).

\section{The effects of scleroderma on the properties of patient's mesenchymal stem cells}

Until now, several types of research have been conducted around comparing the MSCs derived from healthy individuals to MSCs from SSc subjects (SScMSCs) for assessing the effects of scleroderma on the patient's MSCs. Although some of them have differed in parts of the outcomes, the majority has indicated the following results:

- In all of the SSc-MSC types, there isn't a significant difference in phenotype and expression of MSCs specific markers compared to healthy ones (Rozier et al. 2018; Larghero et al. 2008; Scuderi et al. 2013).

- All of the SSc-MSC types are maintained the normal MSCs multi- differentiation ability (Rozier et al. 2018).

- All of the SSc-MSC types are maintained the normal MSCs immune modulator and immune suppressive capability (Rozier et al. 2018; Cipriani et al. 2013a).

- All of the SSc-MSC types are maintained the normal MSCs colony forming unit's capacity (Rozier et al. 2018).

- All of the SSc-MSC types indicate the increases myofibroblastic differentiation (as a hallmark of scleroderma pathogenesis) strength compared to healthy ones (Guiducci et al. 2011).

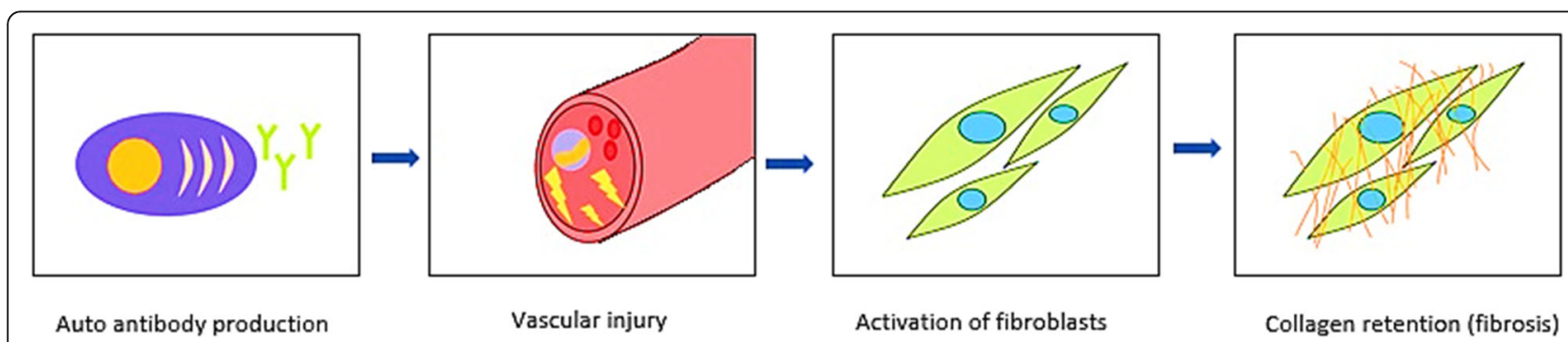

Fig. 1 Pathophysiology of Systemic Sclerosis (SSC). In the pathophysiology of SSc first of all, an immune dysregulation is caused that is displayed by auto antibody production. The mechanism during which the dyscrasias is caused, is not completely understood, but it is proposed that genetics and the environmental factors play important roles in the process. Autoantibodies as well as other factors like high levels of reactive oxygen species(ROS) cause vascular injury, the process that leads to the activation of fibroblasts. Activated fibroblasts produce an unusual high amount of collagen (especially type I) as well as other components of extracellular matrix (ECM) that form an extensive amount of fibrosis (Velier et al. 2019) 
- All of the SSc-MSC types are shown the excess levels of type II transforming growth factor beta (TGF $\beta$ ) receptor (TGF $\beta$ R II) and following that, promoting the TGF $\beta$ signaling pathway and increasing the production of type I collagen target genes compared to healthy ones (Guiducci et al. 2011).

- In SSc- BM- MSCs there is an increasing level of senescence markers compared to healthy ones (Rozier et al. 2018; Guiducci et al. 2011).

- SSc- BM- MSCs can produce more specific markers related to pericytes (as cells that have myofibroblast trans-differentiation tendency) than healthy ones (Cipriani et al. 2013b; Cipriani et al. 2014).

- SSc-AD-MSCs are indicated the reduction of proliferative rate as well as decreases the metabolic, migration and invasion activities compared to healthy ones (Cipriani et al. 2013a; Griffin et al. 2017).

\section{General characters of mesenchymal stem cells and source of extraction}

MSCs are multipotent progenitor cells, which can be extracted from different tissues, including bone marrow (BM), adipose tissue (AD), umbilical cord (UC), placenta (PL), and dental pulp (Maria et al. 2016a; Rozier et al. 2018; Velier et al. 2019; Uji et al. 2015; da Silva et al. 2006). They are known by 3 main characteristics: (1) Plastic adherence, (2) expression of the cell surface markers CD73, CD90, CD105, and lack of expression of the hematopoietic markers CD11b or CD14, CD19 or CD79 $\alpha$, CD34, CD45, human leukocyte antigen-DR (HLA-DR), and (3) capacity of differentiating into adipocytes, chondrocytes, and osteoblasts (Maria et al. 2016a; Rozier et al. 2018; Dominici et al. 2006); moreover, they have functions like supporting hematopoietic stem cells differentiation, cell proliferation as well as anti-fibrotic, antiapoptotic, proangiogenic, anti-bacterial, and antiinflammatory effects (against the mitogen-induced proliferation of T lymphocytes) (Maria et al. 2016a; Rozier et al. 2018; Maumus et al. 2013). These actions are mostly paracrine which means that MSCs secrete effectors in the extracellular space (Rozier et al. 2018; Velier et al. 2019; Maumus et al. 2013; Abbasi-Malati et al. 2018). However, these effects can happen via cell-cell contact (Rozier et al. 2018; Luz-Crawford et al. 2012). On the other hand, MSCs have been proposed to have pericyte like properties (Rozier et al. 2018). Pericytes are microcirculation cells that their cross-talk with EC, regulates angiogenesis (Rozier et al. 2018). Studies have shown that pericytes have multi-lineage differentiation capacities in vitro and they don't have this property in vivo (Rozier et al. 2018; Guimarães-Camboa et al. 2017). Hence, it has been concluded that part of MSCs (BM-MSCs) are pericytes acting as multipotent progenitors and express pericyte specific markers, including a-SMA, neuron-glial antigen 2(NG2), regulator of G protein signaling 5 (RGS5), desmin, and plateletderived growth factor receptors (PDGFb-R) (Rozier et al. 2018; Cipriani et al. 2013b; Cai et al. 2009). MSCs vary in differentiation potential or immunomodulatory capacity based on their source (Rozier et al. 2018; Kern et al. 2006; Keyser et al. 2007). They have pleiotropic activity, so their therapeutic function in different diseases has been evaluated such as rheumatic diseases (Rozier et al. 2018; Ruiz et al. 2016), stroke (Rozier et al. 2018; Toyoshima and Yasuhara 2017), lupus and scleroderma (Rozier et al. 2018; Cras et al. 2015), heart diseases (Rozier et al. 2018; Yu et al. 2017), or bone defects (Rozier et al. 2018; Paduano et al. 2017). In addition, their safety has been proved by hundreds of clinical trials (Rozier et al. 2018; Lalu et al. 2012). In fact, the efficacy of using MSCs in SSc treatment is being assessed by several phase I/II clinical trials (Rozier et al. 2018) of which there is a review in the following parts.

\section{Mechanism of mesenchymal stem cells in counteracting scleroderma symptoms}

MSCs are proposed to play important roles in several diseases via different mechanisms of action. Hereupon, various mediators are secreted through the each of these mechanisms (Rozier et al. 2018; Maumus et al. 2013). In this respect, MSCs take part in SSC in 3 main axes (Fig. 2):

- The anti-fibrotic property prevents collagen accumulation in the skin, lung and digestive system (Rozier et al. 2018; Velier et al. 2019). TGFß1, TGF $\beta R$ II, collagen type I alpha 1 chain (COL1A1), collagen type III alpha 1 chain (COL3A1), hepatocyte growth factor (HGF), matrix metalloproteinases (MMPs)1, MMP2, MMP9, tissue inhibitor of metalloproteinase 1 (TIMP1), miR-1999-3p, miR-151-5p take part in this axis (Rozier et al. 2018; Rubio et al. 2018; Wang et al. 2016).

- The angiogenic properties, go against widespread vasculopathy by using vascular endothelial growth factor (VEGF), insulin-like growth factor-1 (IGF-1), HGF, platelet-derived growth factor (PDGF), and IL6 (Rozier et al. 2018; Velier et al. 2019).

- The anti-inflammatory property counteracts the dysregulation of the immune system. TGF $\beta 1$, IL6, prostaglandin $\mathrm{E}_{2}$ (PGE2), HGF, interferon-gamma (IFN$\gamma)$, IL-10, IL4, tumour necrosis factor alpha (TNF$\alpha)$, glucocorticoid-induced leucine zipper (GILZ), indolamine-2,3-dioxygenase (IDO) and inducible NO synthase (iNOS), TNF- $\alpha$-stimulatedgene- 6 (TSG6), interleukin-1 receptor antagonist (IL-1RA), heme oxygenase-1 (HO-1), and TNF receptor 1 
(TNFR1) are associated with this mechanism (Rozier et al. 2018; Cras et al. 2015; Maria et al. 2017; Peltzer et al. 2018) (Fig. 2).

\section{The attenuation of vasculopathy}

As mentioned earlier, some of the MSCs have pericyte like properties and enhance vasculogenesis through crosstalks with ECs. Herein, in an experimental study, BM-MSCs (positive for $\alpha$-SMA) were purified from $\alpha$ SMA- green fluorescent protein(GFP) transgenic mice in order to study their proliferative and pro-angiogenic characteristics and the conclusion was that $\alpha$-SMA-GFP positive cells can play a role in neovascularization through special cross-talks with ECs (Cai et al. 2009). When ischemia happens in an organ due to the structural vessel abnormalities during SSc, progenitor cells enter blood circulation from bone marrow or peripheral niches. They adhere to the injured sites and mature into the endothelial and vascular smooth muscle cells (Guiducci et al. 2008). Some of the BM-MSCs are proposed to have the characteristics of endothelial progenitor cells (Guiducci et al. 2008; Chopra et al. 2018). Some studies have shown that although BM-MSCs are negative for vascular endothelial growth factor receptor2(VEGFR2), von Willebrand factor (vWF), and vascular endothelial cadherin factors, growing under endothelial conditions, makes them to express those factors (Chopra et al. 2018; Jiang et al. 2002; Oswald et al. 2004; Reyes et al. 2002). Therefore, it is suggested that BM-MSCs can differentiate into ECs and promote collaterals forming through paracrine mechanisms (Chopra et al. 2018; Kinnaird et al. 2004). Oxidative stress is another mechanism contributing to vasculopathy in SSc. ECs exposure to radical oxygen species causes endothelial aging, morphological changes and impairment of cell-cell adhesion. MSCs can attenuate this process by counteracting the immune dysregulation that happens during the pathophysiology of the disease as well as enhancing antioxidant enzyme production (Guiducci et al. 2008).

\section{The attenuation of immune dysregulation}

Immune dysregulation is another underlying mechanism of the disease that is caused by increased levels of inflammation (reflected by the level of AOPPs in serum) and the reduction of total antioxidant capacity of the body (Maria et al. 2016a). Studies have shown that BMMSC treatment in HOCL-induced mouse models significantly increases the mRNA expression of the antioxidant enzymes HO-1 and superoxide dismutase 2 (SOD2) in the lung and Sod2 in the skin. Altogether, these effects imply an enhancement in antioxidant capacity of serum in these mice (Maria et al. 2016a).

\section{The attenuation of fibrosis}

Fibrosis spreading in SSc happens during three main mechanisms. All these mechanisms and the effect of MSC treatment on their suppression are discussed in the following part.

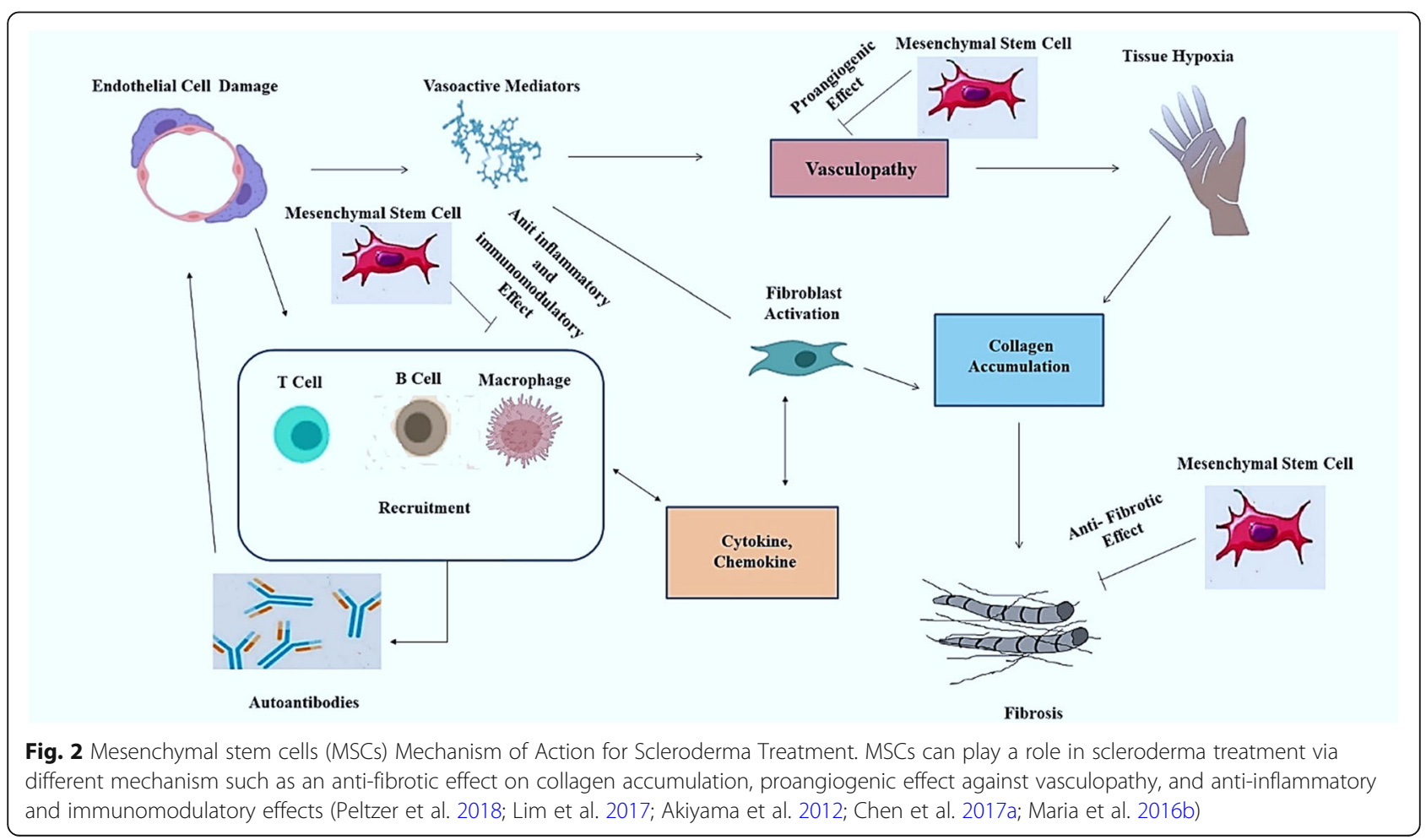


Table 1 Scleroderma Genetics Models (Lakos et al. 2004; Jimenez and Christner 2002)

\begin{tabular}{|c|c|c|c|}
\hline Genetic Model & Category & Specific Features & $\begin{array}{l}\text { Site of } \\
\text { Fibrosis }\end{array}$ \\
\hline Tight skin 1 mouse models(Tsk1/+) & $\begin{array}{l}\text { Models with } \\
\text { spontaneous } \\
\text { mutations }\end{array}$ & $\begin{array}{l}\text { - They are bred as heterozygotes because of lethal homozygous mutation. } \\
\text { - They have thickened skin which is tightly joined to the subcutaneous } \\
\text { tissue. } \\
\text { - The deposition of elastin has risen but there isn't elasticity in the skin. } \\
\text { - They present an emphysema-like pathology in the lung due to the in- } \\
\text { creased elastin. } \\
\text { - They have an enlarged heart and skeleton. } \\
\text { - There is partial duplication of the fibrillin-1 gene as a mutation on } \\
\text { chromosome } 2 \text { which seems to suppress raised levels of TGF } \beta \text { in the } \\
\text { extracellular matrix and following stimulating collagen synthesis. }\end{array}$ & Skin \\
\hline Tight skin 2 mouse models (Tsk2/+) & $\begin{array}{l}\text { Models with } \\
\text { spontaneous } \\
\text { mutations }\end{array}$ & $\begin{array}{l}\text { - They are generated via mutagenic agent ethylnitrosourea. } \\
\text { - Tight skin can be found in the interscapular region. } \\
\text { - The mutation is placed on chromosome } 1 . \\
\text { - They can mimic many characteristics of systemic sclerosis subjects, } \\
\text { containing increased deposition of the dermal extracellular matrix, tight } \\
\text { skin, and autoantibodies. } \\
\text { - They present enhanced transcription percentages of dermal fibroblasts } \\
\text { type I and III collagen. } \\
\text { - Increased autoimmunity have reported in Tsk2/+ models. }\end{array}$ & Skin \\
\hline UCD-200 chickens & $\begin{array}{l}\text { Models with } \\
\text { spontaneous } \\
\text { mutations }\end{array}$ & $\begin{array}{l}\text { - They are identified by infiltration of perivascular lymphocytic, vascular } \\
\text { occlusion caused by endothelial injuries, fibrosis of the skin and visceral } \\
\text { organs, and spotted antinuclear antibodies. } \\
\text { - There is a genetic defect with an autosomal recessive mode of inheritance } \\
\text { or multiple loci interactions. } \\
\text { - Five genes including which have been reported to have importance in } \\
\text { the pathology of systemic sclerosis including (TGFBR1, IGFBP3, EXOC2/ } \\
\text { IRF4, CCR8 (located on chromosome 2), and SOCS1(located at } \\
\text { chromosome 14) have been recognized to present a high association with } \\
\text { the disease. } \\
\text { - Mutation of COL1A2 gene (located on chromosome 2) may play a role in } \\
\text { avian systemic sclerosis. }\end{array}$ & $\begin{array}{l}\text { Skin and } \\
\text { Visceral } \\
\text { organs }\end{array}$ \\
\hline Endothelin-1 mouse models & $\begin{array}{l}\text { Transgenic } \\
\text { models of fibrosis }\end{array}$ & $\begin{array}{l}\text { - There is increased expression of endothelin-1. } \\
\text { - They have endothelial dysfunction. } \\
\text { - They develop glomerulosclerosis and interstitial fibrosis. }\end{array}$ & $\begin{array}{l}\text { Kidney and } \\
\text { Lung }\end{array}$ \\
\hline Fos-related antigen-2 mouse models & $\begin{array}{l}\text { Transgenic } \\
\text { models of fibrosis }\end{array}$ & $\begin{array}{l}\text { - There is overexpressing the Fos-related antigen-2 (FRA-2) } \\
\text { - They show microangiopathy along with progression of skin fibrosis. }\end{array}$ & $\begin{array}{l}\text { Skin and } \\
\text { Lung }\end{array}$ \\
\hline $\begin{array}{l}\text { Type I TGF } \beta \text { receptor transgenic } \\
\text { models }\end{array}$ & $\begin{array}{l}\text { Transgenic } \\
\text { models of fibrosis }\end{array}$ & $\begin{array}{l}\text { - There is upregulating of the type I TGF } \beta \text { receptor in fibroblasts on a Cre- } \\
\text { ER transgenic background. } \\
\text { - There are increasing levels of collagen deposition in the skin of through } \\
\text { the aging. }\end{array}$ & Skin \\
\hline $\begin{array}{l}\text { Kinase-deficient type II TGF } \beta \\
\text { receptor transgenic models }\end{array}$ & $\begin{array}{l}\text { Transgenic } \\
\text { models of fibrosis }\end{array}$ & $\begin{array}{l}\text { - There is a fibroblast-specific transcriptional enhancer (applied to specific- } \\
\text { ally express a kinase-deficient mutant type II TGF } \beta \text { receptor which can in- } \\
\text { volve TGF } \beta \text { ) upstream of the COL1A2 collagen gene. } \\
\text { - There is the lack of immune activation and autoantibodies. }\end{array}$ & $\begin{array}{l}\text { Skin and } \\
\text { Lung }\end{array}$ \\
\hline $\begin{array}{l}\text { PDGF receptor-a transgenic models } \\
\text { of fibrosis }\end{array}$ & $\begin{array}{l}\text { Transgenic } \\
\text { models of fibrosis }\end{array}$ & - There is conditionally expressed PDGF receptor-a activating mutations. & $\begin{array}{l}\text { Skin and } \\
\text { Internal } \\
\text { organs }\end{array}$ \\
\hline Caveolin-1 deficient models & $\begin{array}{l}\text { Knockout models } \\
\text { of fibrosis }\end{array}$ & $\begin{array}{l}\text { - There are raised collagen and fibronectin accumulation along with } \\
\text { increased amounts of myofibroblasts. } \\
\text { - There is oxidative stress condition. }\end{array}$ & Skin \\
\hline $\begin{array}{l}\text { Early growth response protein-1 } \\
\text { knockout mouse models }\end{array}$ & $\begin{array}{l}\text { Knockout models } \\
\text { of fibrosis }\end{array}$ & $\begin{array}{l}\text { - There are reduced amounts of infiltrating inflammatory cells in the skin } \\
\text { along with the reduced dermal thickness and expression of collagen. }\end{array}$ & $\begin{array}{l}\text { Skin and } \\
\text { Lung }\end{array}$ \\
\hline $\begin{array}{l}\text { Friend leukemia integration factor-1 } \\
\text { conditional knockout mouse models }\end{array}$ & $\begin{array}{l}\text { Knockout models } \\
\text { of fibrosis }\end{array}$ & $\begin{array}{l}\text { - There is risen vascular permeability. } \\
\text { - They mimic the collagen fibril formation abnormalities in systemic } \\
\text { sclerosis. }\end{array}$ & Skin \\
\hline $\begin{array}{l}\text { Macrophage chemoattractant } \\
\text { protein-1 mouse models }\end{array}$ & $\begin{array}{l}\text { Knockout models } \\
\text { of fibrosis }\end{array}$ & $\begin{array}{l}\text { - There are reduced fibrotic replies after the injection of basic fibroblast } \\
\text { growth factor and connective tissue growth factor into the skin. } \\
\text { - There are fewer mast cells, reduction of macrophage recruitment, and } \\
\text { fewer CD4+ T-cell amounts. }\end{array}$ & Skin \\
\hline $\begin{array}{l}\text { Microsomal prostaglandin E2 } \\
\text { synthase-1 knockout models }\end{array}$ & $\begin{array}{l}\text { Knockout models } \\
\text { of fibrosis }\end{array}$ & $\begin{array}{l}\text { - There are bleomycin-induced fibrosis resistant, a-smooth muscle actin } \\
\text { levels reduction, and macrophages numbers reduction. }\end{array}$ & $\begin{array}{l}\text { Skin and } \\
\text { Lung }\end{array}$ \\
\hline
\end{tabular}


Table 1 Scleroderma Genetics Models (Lakos et al. 2004; Jimenez and Christner 2002) (Continued)

\begin{tabular}{|c|c|c|c|}
\hline Genetic Model & Category & Specific Features & $\begin{array}{l}\text { Site of } \\
\text { Fibrosis }\end{array}$ \\
\hline $\begin{array}{l}\text { Peroxisome proliferator-activated } \\
\text { receptor-gamma deficient models }\end{array}$ & $\begin{array}{l}\text { Knockout models } \\
\text { of fibrosis }\end{array}$ & $\begin{array}{l}\text { - There is more extensive skin thickening with bleomycin compared to } \\
\text { wild-type. } \\
\text { - They can help to determine the function of this protein in collagen } \\
\text { synthesis. }\end{array}$ & Skin \\
\hline $\begin{array}{l}\text { PTEN conditional knockout mouse } \\
\text { models }\end{array}$ & $\begin{array}{l}\text { Knockout models } \\
\text { of fibrosis }\end{array}$ & $\begin{array}{l}\text { - There are developed thickened skin and collagen deposition along with } \\
\text { raised a-smooth muscle actin-bearing fibroblasts numbers, connective tis- } \\
\text { sue growth factor-positive fibroblasts, and proliferating cell nuclear } \\
\text { antigen-positive fibroblasts. }\end{array}$ & Skin \\
\hline Relaxin knockout mouse models & $\begin{array}{l}\text { Knockout models } \\
\text { of fibrosis }\end{array}$ & - There is developed skin collagen deposition over time. & Skin \\
\hline
\end{tabular}

Tsk1/+ Tight skin1 mouse, Tsk2/+ Tight skin2 mouse, TGF $\beta$ Transforming growth factor beta, TGFBR1 Transforming Growth Factor Beta Receptor 1, IGFBP3 Insulinlike growth factor-binding protein 3, CCR3 C-C chemokine receptor type 3, SOCS1 Suppressor of cytokine signaling 1, COL1A2 Collagen Type I Alpha 2 Chain, FRA-2 Fos-related antigen-2, ER Estrogen Receptor, PDGF Platelet-derived growth factor

- Reducing the infiltration of immune cells into the skin and lung

Studies have shown that a polymorphic infiltration of immune cells (including CD3+ $\mathrm{T}$ cells and F4/80+ and CD11b + macrophages) as well as myofibroblasts (by $\alpha$ SMA1 and TGF $\beta 1)$ plays an important role in the skin and lung fibrosis in bleomycin and $\mathrm{HOCl}$-induced models (Maria et al. 2016a; Okamura et al. 2020; Yoshizaki et al. 2010). However, PAX-51 B cell infiltration wasn't observed in the organ sections (Maria et al. 2016a; Okamura et al. 2020). A study showed macrophages, neutrophils, and lymphocytes penetration in the lung tissue following intra-tracheal bleomycin injection (Lee et al. 2014). In these studies, AD-MSCs treatment significantly reduced the infiltration of CD4+ and CD8+ $\mathrm{T}$ cells, and $\mathrm{CD} 11 \mathrm{~b}+$ macrophages into the skin compared to the control group (phosphate-buffered saline (PBS)-treated group) (Okamura et al. 2020). The same effect was observed in BM-MSC treatment. More precisely, intra alveolar septa showed almost normal architecture and fewer parenchymal cell infiltration was observed in the lung and skin (Maria et al. 2016a).

\section{- Reducing mRNA expression of fibrogenic cytokines and collagen}

Producing fibrogenic cytokines (including IL-1b, IL-6, IL-10, IL-13, and TNF- $\alpha$ ) is another mechanism that results in the skin and lung fibrosis of SSc in animal models (Maria et al. 2016a; Okamura et al. 2020; Duncan and Berman 1989; Hasegawa et al. 2011; Horikawa et al. 2005; Matsushita et al. 2007; Matsushita et al. 2006). By contrast, IFN- $\gamma$ (Th1 cytokine) is an antifibrotic cytokine (Okamura et al. 2020; Yamamoto et al. 2000). A study has shown that AD-MSCs treatment in bleomycin-induced mouse models reduces IL-6, IL-13, TNF- $\alpha$ and pro COL1A2 gene mRNA expression in the skin compared to the control group (Okamura et al.
2020). In addition, IFN- $\gamma$ mRNA levels in the skin of $\mathrm{AD}-\mathrm{MSCs}$-treated group were comparable to the control group (Okamura et al. 2020). BM-MSC treatment also resulted in lower levels of IL-1b,IL-6, IL-10 as well as reduced expression levels of COL1, COL3, TGF $\beta 1$, and $\alpha$-SMA genes in the skin and reduced levels of IL$1 b$, TNF- $\alpha$, and IL-10 in the lung in HOCL-induced mouse models (Maria et al. 2016a). BM-MSC treatment also reduced expression of transcripts for tissue remodeling parameters, such as tissue inhibitor of metalloproteinases 1 (TIMP-1), HGF, VEGF, and MMP9 in the skin (Maria et al. 2016a). However, the levels of these parameters were a bit different in the lung tissue (Maria et al. 2016a). BM-MSC treatment affected the expression of tissue remodeling parameters in this way: MMp1/ TIMP-1 ratio was increased, along with the reduction of TGFBRII, HGF, MMP9, and VEGFA gene expression (Maria et al. 2016a).

- Decreasing the frequency of cytokine-producing CD4+ $T$ cells and effector $B$ cells in the spleen in scleroderma models

Coming to the number of regulatory and cytokineproducing $\mathrm{T}$ cells, and effector/regulatory $\mathrm{B}$ cells in the spleen, a study has shown that AD-MSCs treatment reduces the number of TNF- $\alpha$, IL-13 and IL-17-producing CD4+ T cells and IL-6-producing effector B cells in the spleen of bleomycin models. Besides, AD-MSCs can lower the level of IL-13 and IL-17 expression from CD4+ T cells. However, AD-MSCs doesn't affect the number of T and B regulatory cells (Okamura et al. 2020).

\section{Animal modeling for experimental studies of scleroderma}

In order to be able to have an overall view of the preclinical data accessible about various diseases such as SSc, reviewing the main features of different types of animal models that are most commonly used in this field 
Table 2 Preclinical Inducible Models in Studies of Systemic Sclerosis

\begin{tabular}{|c|c|c|c|c|c|c|}
\hline $\begin{array}{l}\text { Target } \\
\text { preclinical } \\
\text { feature }\end{array}$ & $\begin{array}{l}\text { Animal } \\
\text { Models }\end{array}$ & $\begin{array}{l}\text { Observed } \\
\text { Characteristics }\end{array}$ & $\begin{array}{l}\text { The Underlying Mechanisms } \\
\text { of Model Designing }\end{array}$ & Advantages & Disadvantages & References \\
\hline $\begin{array}{l}\text { Systemic } \\
\text { phenotype of } \\
\text { the disease }\end{array}$ & $\begin{array}{l}\text { HOCl-injected } \\
\text { mice }\end{array}$ & $\begin{array}{l}\text {-skin, lung and kidney } \\
\text { implication } \\
\text {-vascular abnormalities } \\
\text {-autoantibodies } \\
\text { production } \\
\text { - } \uparrow C D 4+\text {-cell and B-cell } \\
\text { in the spleen }\end{array}$ & $\begin{array}{l}\text { HOCl injection } \rightarrow \uparrow R O S: \\
-\uparrow c o l l a g e n \text { and a-SMA produc- } \\
\text { tion in skin } \\
\text { - anti-DNA topoisomerase-1 } \\
\text { autoantibodies production } \rightarrow \\
\text { systemic symptoms } \\
\text { HOCl injection } \rightarrow \uparrow A O P P \rightarrow \\
\text { systemic fibrosis }\end{array}$ & $\begin{array}{l}\text {-presenting the key } \\
\text { features of the human } \\
\text { disease (in three main } \\
\text { aspects of fibrosis, } \\
\text { inflammation and } \\
\text { vasculopathy) } \\
\text { - Presenting the role of } \\
\text { ROS and AOPPs in } \\
\text { the pathogenesis of } \\
\text { SSC }\end{array}$ & ND & $\begin{array}{l}\text { (Rozier et al. } \\
\text { 2018; Asano } \\
\text { and Sato } \\
\text { 2013; Morin } \\
\text { et al. 2015) }\end{array}$ \\
\hline Skin fibrosis & $\begin{array}{l}\text { Vinyl Chloride } \\
\text { Injected mice }\end{array}$ & $\begin{array}{l}\text {-skin and spleen fibrosis } \\
\text { and cell infiltration } \\
-\uparrow I \text { IL- } 4 \text { and IL-13 during } \\
\text { a Th2 immune response }\end{array}$ & $\begin{array}{l}\text { vinyl chloride injection } \rightarrow \\
\text { activation of micro chimeric } \\
\text { fetal cells } \rightarrow \text { cell division } \rightarrow \\
\text { symptoms presentation }\end{array}$ & $\begin{array}{l}\text {-showing the role of } \\
\text { micro chimeric fetal } \\
\text { circulating cells and } \\
\text { chemical exposure in } \\
\text { the pathogenesis of } \\
\text { SSc } \\
\text {-an easily reproducible } \\
\text { model }\end{array}$ & ND & $\begin{array}{l}\text { (Morin et al. } \\
\text { 2015; } \\
\text { Storkanova } \\
\text { and Tomcik } \\
\text { 2017; } \\
\text { Christner } \\
\text { et al. 2000) }\end{array}$ \\
\hline \multirow[t]{3}{*}{ Lung fibrosis } & $\begin{array}{l}\text { Silica-induced } \\
\text { lung fibrosis } \\
\text { mice }\end{array}$ & $\begin{array}{l}\text { - pulmonary tissue } \\
\text { fibrosis }\end{array}$ & $\begin{array}{l}\text { instillation of silica } \rightarrow \\
\text { macrophage activation } \rightarrow \\
\text { phagocytosis of silica } \\
\text { particles } \rightarrow \text { pro-fibrotic cytoki- } \\
\text { nes(PDGF, TGF } \beta \text { ) production } \rightarrow \\
\text { lung fibrosis }\end{array}$ & $\begin{array}{l}\text {-mimicking the } \\
\text { pulmonary phenotype } \\
\text { of long-term exposure } \\
\text { to silica dust(as a per- } \\
\text { manent fibrotic } \\
\text { stimuli) }\end{array}$ & $\begin{array}{l}\text {-an expensive animal } \\
\text { model } \\
\text {-a time consuming } \\
\text { process } \\
\text {-specialized equipment } \\
\text { requirement } \\
\text {-lacking the } \\
\text { characteristics of UIP }\end{array}$ & $\begin{array}{l}\text { (Storkanova } \\
\text { and Tomcik } \\
\text { 2017) }\end{array}$ \\
\hline & $\begin{array}{l}\text { FITC induced } \\
\text { lung fibrosis } \\
\text { mice }\end{array}$ & $\begin{array}{l}\text {-pulmonary edema, } \\
\text { inflammation and } \\
\text { fibrosis }\end{array}$ & $\begin{array}{l}\text { FITC usage: } \\
\text { - binding to the protein in the } \\
\text { lungs } \rightarrow \text { formation of a new } \\
\text { antigen } \rightarrow \text { antibody formation } \\
-\uparrow \text { mononuclear cells and } \\
\text { neutrophils infiltration } \rightarrow \text { acute } \\
\text { lung injury } \\
-\uparrow C C L 12 \text { and } C C L 2 \rightarrow \uparrow C C R 2 \\
\text { expressing fibroblasts } \rightarrow \\
\text { pulmonary fibrosis }\end{array}$ & $\begin{array}{l}\text {-fibrosis detection } \\
\text { using green } \\
\text { fluorescence. } \\
\text {-the phenotype occurs } \\
\text { rather fast (during 14- } \\
28 \text { days) and continues } \\
\text { for at least } 6 \text { months. }\end{array}$ & $\begin{array}{l}\text {-lacking the } \\
\text { characteristics of UIP }\end{array}$ & $\begin{array}{l}\text { (Storkanova } \\
\text { and Tomcik } \\
\text { 2017; Chung } \\
\text { et al. 2003) }\end{array}$ \\
\hline & $\begin{array}{l}\text { Radiation- } \\
\text { induced lung } \\
\text { fibrosis mice }\end{array}$ & $\begin{array}{l}\text {-pulmonary tissue } \\
\text { fibrosis }\end{array}$ & $\begin{array}{l}\text { Radiation } \rightarrow \text { pneumocystis I and } \\
\| \text { death } \rightarrow \text { the production of } \\
\text { pro-inflammatory and pro- } \\
\text { fibrotic cytokines (TGF } \beta \text {, TNF-a) } \\
\text { by macrophages } \rightarrow \text { fibrosis }\end{array}$ & $\begin{array}{l}\text {-presenting the } \\
\text { characteristics of UIP. }\end{array}$ & $\begin{array}{l}\text {-an expensive animal } \\
\text { model } \\
\text {-a time consuming } \\
\text { process }\end{array}$ & $\begin{array}{l}\text { (Storkanova } \\
\text { and Tomcik } \\
\text { 2017) }\end{array}$ \\
\hline $\begin{array}{l}\text { Lung fibrosis / } \\
\text { Immunogenic/ } \\
\text { inflammatory } \\
\text { features }\end{array}$ & $\begin{array}{l}\text { Bleomycin- } \\
\text { Injected mice }\end{array}$ & $\begin{array}{l}\text {-lung and skin fibrosis } \\
\text { - }- \text { hydroxyproline } \\
-\uparrow \text { type-I collagen } \\
\text {-Antinuclear } \\
\text { autoantibodies } \\
\text { production (anti-Scl-70, } \\
\text { anti-U1-RNP, and anti- } \\
\text { histone) }\end{array}$ & $\begin{array}{l}\text { Bleomycin } \\
\text { injection } \rightarrow \uparrow R O S \rightarrow \text { endothelial } \\
\text { cell damage and } \uparrow \text { adhesion } \\
\text { molecules } \rightarrow \text { leukocytes } \\
\text { attraction and fibroblast } \\
\text { activation } \rightarrow \text { fibrosis }\end{array}$ & $\begin{array}{l}\text {-presenting some of } \\
\text { the early inflammatory } \\
\text { symptoms of the } \\
\text { disease. } \\
\text {-useful to test the } \\
\text { efficacy of anti-fibrotic } \\
\text { therapeutics } \\
\text {-useful to assess the } \\
\text { potential of the pro- } \\
\text { inflammatory genes of } \\
\text { the patient }\end{array}$ & $\begin{array}{l}\text {-not presenting the } \\
\text { typical clinical features } \\
\text { and autoantibody } \\
\text { patterns of the disease }\end{array}$ & $\begin{array}{l}\text { (Rozier et al. } \\
\text { 2018; Morin } \\
\text { et al. 2015; } \\
\text { Yamamoto } \\
\text { 2010) }\end{array}$ \\
\hline $\begin{array}{l}\text { Immunogenic/ } \\
\text { inflammatory } \\
\text { features }\end{array}$ & Scl-GVHD mice & $\begin{array}{l}\text {-fibrosis formation and } \\
\text { chronic inflammation of } \\
\text { the skin, lung, and } \\
\text { gastrointestinal tract } \\
\text { - } \uparrow C C L 2, C C L 5, C C L 17, \\
\text { IFN- } \gamma \text {-inducible chemo- } \\
\text { kines, PDGF, CTGF, FGF, } \\
\text { EGF, NGF, VEGF and ad- } \\
\text { hesion molecules in the } \\
\text { skin }\end{array}$ & $\begin{array}{l}\text { BM and spleen cells } \\
\text { transplantation into BALB/CJ }(\mathrm{H}- \\
\text { 2d) mice } \rightarrow \text { the donor immune } \\
\text { cells infiltration+ auto-reactive } \\
\text { host T cells escape from thymic } \\
\text { negative selection }\end{array}$ & $\begin{array}{l}\text {-demonstrating many } \\
\text { clinical and histological } \\
\text { similarities to } \\
\text { scleroderma }\end{array}$ & $\begin{array}{l}\text {-ND on symptoms of } \\
\text { vasculopathy } \\
\text { presentation in mice } \\
\text { while vasculopathy is } \\
\text { one the signs of } \\
\text { patients with Scl-GVHD }\end{array}$ & $\begin{array}{l}\text { (Morin et al. } \\
\text { 2015; } \\
\text { Yamamoto } \\
\text { 2010) }\end{array}$ \\
\hline $\begin{array}{l}\text { Pulmonary } \\
\text { atrial } \\
\text { hypertension } \\
\text { (PAH) }\end{array}$ & $\begin{array}{l}\text { chronic } \\
\text { hypoxia+ } \\
\text { semaxanib } \\
\text { (SU5416)- }\end{array}$ & $-P A H$ & $\begin{array}{l}\text { hypoxia } \rightarrow \text { pro-inflammatory cy- } \\
\text { tokines secretion } \\
\text { SU5416: } \\
\text { - } \text { growth factors (FGF, }\end{array}$ & $\begin{array}{l}\text {-exhibiting the } \\
\text { pathophysiological } \\
\text { role of endothelial } \\
\text { proliferation of }\end{array}$ & $\begin{array}{l}\text {-the hypoxia-induced } \\
\text { PAH is slight and } \\
\text { reversible }\end{array}$ & $\begin{array}{l}\text { (Storkanova } \\
\text { and Tomcik } \\
\text { 2017; Nicolls } \\
\text { et al. 2012) }\end{array}$ \\
\hline
\end{tabular}


Table 2 Preclinical Inducible Models in Studies of Systemic Sclerosis (Continued)

\begin{tabular}{|c|c|c|c|c|c|c|}
\hline $\begin{array}{l}\text { Target } \\
\text { preclinical } \\
\text { feature }\end{array}$ & $\begin{array}{l}\text { Animal } \\
\text { Models }\end{array}$ & $\begin{array}{l}\text { Observed } \\
\text { Characteristics }\end{array}$ & $\begin{array}{l}\text { The Underlying Mechanisms } \\
\text { of Model Designing }\end{array}$ & Advantages & Disadvantages & References \\
\hline & $\begin{array}{l}\text { induced PAH } \\
\text { mice }\end{array}$ & & $\begin{array}{l}\text { PDGF) } \rightarrow \text { endothelial cells } \\
\text { proliferation } \rightarrow \text { PAH } \\
\text { - } \uparrow \text { shear stress in the artery } \\
\text { wall } \rightarrow \text { angioobliterative PAH }\end{array}$ & $\begin{array}{l}\text { pulmonary artery in } \\
\text { PAH }\end{array}$ & & \\
\hline & $\begin{array}{l}\text { MCTP- induced } \\
\text { PAH rats }\end{array}$ & $-\mathrm{PAH}$ & $\begin{array}{l}\text { MCTP } \rightarrow \text { endothelium and } \\
\text { smooth } \\
\text { muscle cell proliferation and } \\
\text { mononuclear inflammatory cells } \\
\text { infiltration } \rightarrow \text { PAH }\end{array}$ & $\begin{array}{l}\text {-presenting the acute } \\
\text { process of PAH }\end{array}$ & $\begin{array}{l}\text {-the induced } \\
\text { phenotype is easily } \\
\text { treatable that is } \\
\text { different from PAH in } \\
\text { human SSc }\end{array}$ & $\begin{array}{l}\text { (Storkanova } \\
\text { and Tomcik } \\
\text { 2017; } \\
\text { Stenmark } \\
\text { et al. 2009) }\end{array}$ \\
\hline & $\begin{array}{l}\text { SU5416- } \\
\text { induced PAH } \\
\text { athymic rats }\end{array}$ & -severe PAH & $\begin{array}{l}\text { macrophage, B cell and anti- } \\
\text { endothelial antibodies } \rightarrow \text { pul- } \\
\text { monary artery inflammation } \rightarrow \\
\text { lack of regulatory T cell } \rightarrow \text { se- } \\
\text { vere PAH }\end{array}$ & $\begin{array}{l}\text {-studying the function } \\
\text { of T reg anti- } \\
\text { inflammatory cells in } \\
\text { counteracting PAH in } \\
\text { SSc patients. }\end{array}$ & ND & $\begin{array}{l}\text { (Storkanova } \\
\text { and Tomcik } \\
\text { 2017; Nicolls } \\
\text { et al. 2012) }\end{array}$ \\
\hline & $\begin{array}{l}\mathrm{ET}_{\mathrm{A}} \mathrm{R} \text { and } \mathrm{AT}_{1} \mathrm{R} \\
\text { antibodies } \\
\text { injected mice }\end{array}$ & $\begin{array}{l}\text { - obliterative } \\
\text { vasculopathy of } \\
\text { pulmonary vessels } \\
\text {-PAH }\end{array}$ & $\begin{array}{l}\text { anti-ET }{ }_{A} R \text { and anti-AT }{ }_{1} R \text { injec- } \\
\text { tion } \rightarrow \uparrow a-S M A \text { expression and } \\
\text { lymphocyte infiltration in peri- } \\
\text { vascular areas } \rightarrow \text { obliterative } \\
\text { vasculopathy, } \uparrow \text { vascular reactiv- } \\
\text { ity and vascular remodeling }\end{array}$ & $\begin{array}{l}\text { - useful to assess the } \\
\text { roles of } E T_{A} R \text { and } A T_{1} R \\
\text { antibodies in the } \\
\text { disease pathogenesis }\end{array}$ & ND & $\begin{array}{l}\text { (Morin et al. } \\
\text { 2015; Becker } \\
\text { et al. 2014) }\end{array}$ \\
\hline \multirow[t]{3}{*}{$\begin{array}{l}\text { Phenotypes } \\
\text { caused by a } \\
\text { particular } \\
\text { factor }\end{array}$} & $\begin{array}{l}\text { topoisomerase- } \\
1+\text { CFA } \\
\text { injected mice }\end{array}$ & $\begin{array}{l}\text {-skin and lung fibrosis } \\
\text { - } \uparrow \mid \mathrm{L}-6, \mathrm{TGF}-\beta 1, \mathrm{LL}-17 \text { and } \\
\text { IL-10 } \\
\text {-Th2 and Th17 in BAL }\end{array}$ & $\begin{array}{l}\text { topoisomerase- } 1+\text { CFA } \\
\text { injection } \rightarrow \uparrow T h 2 / T h 17 \text { immune } \\
\text { pathway } \rightarrow \text { skin sclerosis, ILD, } \\
\text { and } \uparrow \text { inflammatory cytokines }\end{array}$ & $\begin{array}{l}\text {-mimicking diffuse SSC } \\
\text { symptoms } \\
\text {-proposing the } \\
\text { relationship between } \\
\text { responses to topo I } \\
\text { and the pathogenesis } \\
\text { of the disease. } \\
\text {-advantageous for } \\
\text { studying the effects of } \\
\text { immunosuppressive } \\
\text { and anti-inflammatory } \\
\text { drugs on SSc. }\end{array}$ & ND & $\begin{array}{l}\text { (Asano and } \\
\text { Sato 2013; } \\
\text { Morin et al. } \\
\text { 2015) }\end{array}$ \\
\hline & $\begin{array}{l}\text { Angiotensin II- } \\
\text { Induced mice }\end{array}$ & $\begin{array}{l}\text { - } \uparrow \text { collagen, CTGF, TGF } \beta \\
\text { and pSmad } 2 \text { expression } \\
\text { - } \uparrow \text { hydroxyproline } \\
\text { content in skin } \\
\text { - } \text { immune cell } \\
\text { infiltration into the skin } \\
\text { - } \text { vascular injury } \\
\text { markers(VWF, TSP-1 and } \\
\text { MMP-12) }\end{array}$ & $\begin{array}{l}\text {-exogenous angiotensin II: } \\
\text {-collagen I receptor } \\
\text { stimulation } \rightarrow \text { skin fibrosis } \\
\text {-the dysregulation of } \\
\text { endothelial-to-mesenchymal } \\
\text { transition } \rightarrow \text { activated fibroblasts } \\
\text { production }\end{array}$ & $\begin{array}{l}\text {-showing the role of } \\
\text { the renin-angiotensin } \\
\text { pathway in the } \\
\text { process of fibrosis } \\
\text { formation } \\
\text {-advantageous for } \\
\text { studying the effects of } \\
\text { anti-inflammatory } \\
\text { drugs on SSc. }\end{array}$ & $\begin{array}{l}\text {-not mimicking the } \\
\text { auto-immune process } \\
\text { of the human disease. } \\
\text {-blockage of related } \\
\text { signaling pathway has } \\
\text { little effect on the } \\
\text { pathophysiology of the } \\
\text { disease }\end{array}$ & $\begin{array}{l}\text { (Asano and } \\
\text { Sato 2013; } \\
\text { Morin et al. } \\
\text { 2015) }\end{array}$ \\
\hline & $\begin{array}{l}\text { Exogenous } \\
\text { TGF } \beta+\text { CTGF } \\
\text { injected mice }\end{array}$ & $\begin{array}{l}\text {-ECM-rich skin fibrosis } \\
\text { - } \uparrow \text { macrophages }\end{array}$ & $\begin{array}{l}\text { TGF } \beta \rightarrow \text { granulation and fibrotic } \\
\text { tissue formation } \\
\mathrm{CTGF} \text { and bFGF } \rightarrow \text { sustained } \\
\uparrow \text { collagen I gene expression } \rightarrow \\
\text { fibrosis maintenance }\end{array}$ & $\begin{array}{l}\text {-presenting sustained } \\
\text { fibrosis due to the use } \\
\text { of CTGF in } \\
\text { combination with } \\
\text { TGF } \beta\end{array}$ & ND & $\begin{array}{l}\text { (Yamamoto } \\
\text { 2017) }\end{array}$ \\
\hline
\end{tabular}

HOCI Hypochlorous Acid, CCR CC chemokine receptor, FITC Fuorescein Isothiocyanate, TNF- $a$ Tumour Necrosis Factor Alpha, UIP Usual Interstitial Pneumonia, RNP Ribonucleoprotein, ROS Reactive Oxygen Species, CCL C-C Chemokine Ligand, IFN- $\gamma$ Interferon-Gamma, NGF Nerve Growth Factor, EGF Epidermal growth factor, GVHD Graft versus host disease, VEGF Vascular Endothelial Growth Factor, FGF Fibroblast Growth Factor, PDGF Platelet-Derived Growth Factor, SU5416 Semaxanib, MCTP Monocrotaline, PAH Pulmonary Atrial Hypertension, $E T_{A} R$ Anti-endothelin receptor Type-A, $A T_{1} R$ Antiangiotensin Receptor Type - 1, ILD Interstitial Lung Disease, IL Interleukin, CFA Complete Freund's Adjuvant, Th T helper, pSmad2 phospho-Smad2, $a$ SMA Alpha-Smooth Muscle Actin, vWF von Willebrand Factor, TSP-1 Thrombospondin-1, MMP Matrix Metalloproteinases, SSc Systemic Sclerosis, ECM Extracellular Matrix, bFGF Basic Fibroblast Growth Factor, CTGF Connective Tissue Growth Factor, TGF $\beta$ Transforming Growth Factor beta, ND No Data

of study seems to be necessary (Larijani et al. 2019; Goodarzi et al. 2019b). Herein, current review also helps the researchers with the design of relevant animal studies via providing the pros and cons of each model in detail. The SSc preclinical models are divided in two main categories based on the process of the target phenotype developing: the genetic and inducible animal models.

\section{The genetic animal models}

According to studies, scleroderma genetics animal models fall into the following three general categories (Lakos et al. 2004; Artlett 2014; Jimenez and Christner 2002) (Table 1):

1. SSc models which have emerged through spontaneous mutations (lead to raised extracellular 
Table 3 Some of The MSC-based Animal Studies for Scleroderma

\begin{tabular}{|c|c|c|c|c|}
\hline References & Animal models & Origin and dose of MSCs & $\begin{array}{l}\text { The site of } \\
\text { stem cell } \\
\text { injection }\end{array}$ & Observed outcomes \\
\hline $\begin{array}{l}\text { (Okamura } \\
\text { et al. 2020) }\end{array}$ & $\begin{array}{l}\text { Bleomycin intradermic } \\
\text { injection/mouse(daily, } 4 \text { weeks) and Scl- } \\
\text { cGVHD(irradiated with } 400 \text { cGy twice a } \\
\text { day/1 day) }\end{array}$ & $2 \times 10^{5}$ syngeneic AD-MSCs & intravenous & $\begin{array}{l}\downarrow \text { dermal thickness } \\
\downarrow \text { skin fibrosis (both models) } \\
\downarrow \text { lung fibrosis (both models) } \\
\downarrow \text { infiltration of immune cells into the } \\
\text { skin } \\
\downarrow \text { COL1A2 mRNA expression } \\
\downarrow \downarrow L-6 \text { and IL-13 } \\
\downarrow \| L-10 \text { and IFN- } \gamma \\
\downarrow \text { frequency of cytokine producing } \\
\text { CD4+ T cells and effector B cells in } \\
\text { the spleen }\end{array}$ \\
\hline $\begin{array}{l}\text { (Maria et al. } \\
\text { 2018) }\end{array}$ & $\begin{array}{l}\mathrm{HOCl} \text { intradermic } \\
\text { injection/mouse } \\
\text { (daily, } 42 \text { days) }\end{array}$ & $2.5 \times 10^{5}$ syngeneic BM-MSCs & intravenous & 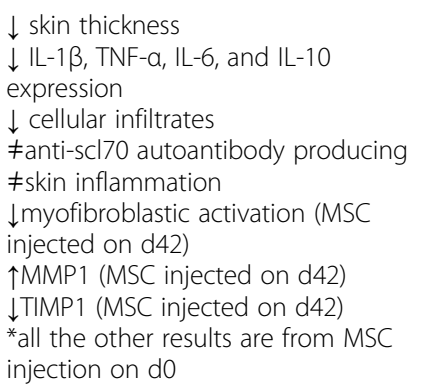 \\
\hline $\begin{array}{l}\text { (Rubio } \\
\text { et al. 2018) }\end{array}$ & Bleomycin intratracheal/mouse & $5 \times 105$ syngeneic AD-MSCs & intravenous & 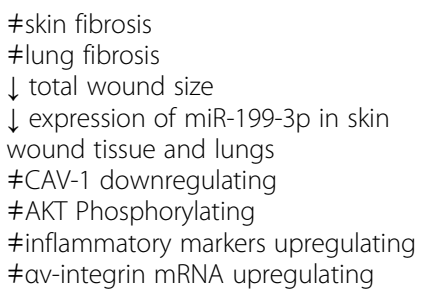 \\
\hline $\begin{array}{l}\text { (Lan et al. } \\
\text { 2017) }\end{array}$ & Bleomycin intratracheal/mouse & $\begin{array}{l}2.5 \times 10^{5} \text { syngeneic OSM } \\
\text { preconditioned BM-MSCs }\end{array}$ & intratracheal & $\begin{array}{l}\uparrow \text { wound healing } \\
\downarrow \text { collagen content } \\
\downarrow \text { ECM synthesis } \\
\downarrow \text { inflammatory mediators } \\
\downarrow \text { lung edema } \\
\downarrow \text { total cells and neutrophils in BAL } \\
\text { fluid } \\
\downarrow \text { fibrotic factors in the lung } \\
\downarrow \text { histological changes }\end{array}$ \\
\hline $\begin{array}{l}\text { (Jiang et al. } \\
\text { 2017) }\end{array}$ & $\begin{array}{l}\text { Bleomycin subcutaneous/mouse(daily, } 21 \\
\text { days) }\end{array}$ & $\begin{array}{l}1 \times 10^{6} \text { syngeneic BM-MSCs } \\
\text { overexpressing Trx-1 }\end{array}$ & subcutaneous & $\begin{array}{l}\downarrow \text { apoptosis } \\
\downarrow \text { Bax } \\
\downarrow \text { cleaved caspase } 3 \\
\uparrow B c \text {-2 } \\
\text { \#Dermal thickening } \\
\downarrow \text { TGF } \beta \text {, a-SMA, fibronectin and colla- } \\
\text { gen } 1 \text { expression in the skin }\end{array}$ \\
\hline $\begin{array}{l}\text { (Huleihel } \\
\text { et al. 2017) }\end{array}$ & Bleomycin intratracheal/mouse & $\begin{array}{l}5 \times 105 \text { human BM-MSCs overex- } \\
\text { pressing let7d }\end{array}$ & intravenous & $\begin{array}{l}\downarrow \text { weight loss } \\
\downarrow \text { CD } 45 \text { positive cells in the lung } \\
\downarrow \text { collagen transcript levels } \\
\text { NC in a-SMA, HMGA-2, N-Cadherin } \\
\text { and FSP- } 1 \text { expression }\end{array}$ \\
\hline $\begin{array}{l}\text { (Chen et al. } \\
\text { 2017b) }\end{array}$ & Tsk1/+ mouse & $\begin{array}{l}1 \times 10^{5} \text { allogeneic BM-MSC } / 10 \mathrm{~g} \\
\text { bodyweight }\end{array}$ & intravenous & $\begin{array}{l}\uparrow \text { osteoblast and osteoclast numbers in } \\
\text { the femurs } \\
\uparrow \text { serum levels of type I collagen cross- } \\
\text { linked telopeptide (CTX) and sRANKL } \\
\uparrow \text { bone formation rate } \\
\uparrow C F U-F \\
\text { Improvement of osteogenic } \\
\text { differentiation of BM-MSCs in mice } \\
\uparrow R u n \times 2, \text { ALP, and OCN } \\
\downarrow \text { adipocytes in the bone marrow }\end{array}$ \\
\hline
\end{tabular}


Table 3 Some of The MSC-based Animal Studies for Scleroderma (Continued)

\begin{tabular}{|c|c|c|c|c|}
\hline References & Animal models & Origin and dose of MSCs & $\begin{array}{l}\text { The site of } \\
\text { stem cell } \\
\text { injection }\end{array}$ & Observed outcomes \\
\hline & & & & $\downarrow P P A R y$ and LPL expression \\
\hline $\begin{array}{l}\text { (Maria et al. } \\
\text { 2016b) }\end{array}$ & $\begin{array}{l}\mathrm{HOCl} \text { intradermic } \\
\text { injection/mouse(daily, } 42 \text { days) }\end{array}$ & $\begin{array}{l}2.510^{5} \text { human BM-MSCs/ AD- } \\
\text { MSCs }\end{array}$ & intravenous & $\begin{array}{l}\downarrow \text { rate in skin thickness formation } \\
\downarrow \text { total collagen deposition in skin and } \\
\text { lungs } \\
\downarrow \text { COL1, COL3 and a-SMA gene } \\
\text { expression } \\
\downarrow \text { infiltration of CD3+ T lymphocytes } \\
\text { and F4/80+ macrophages } \\
\uparrow M M P 1 / T I M P 1 \text { ratio(higher in human } \\
\text { AD-MSCs) } \\
\downarrow \text { TNF-a, IL-1b and IL-10 in skin(lower } \\
\text { in human AD-MSCs) } \\
\downarrow \text { pulmonary fibrosis } \\
\downarrow \text { COL1 and a-SMA transcripts } \\
\downarrow \text { TNF-a } \\
\downarrow \text { IL-1b (lower in human AD-MSCs) } \\
\text { NC in IL-10 }\end{array}$ \\
\hline $\begin{array}{l}\text { (Cahill et al. } \\
\text { 2016) }\end{array}$ & Bleomycin intranasal/mice & $\begin{array}{l}5 \times 104 \text { allogeneic or HGF } \\
\text { knockdown BM-MSCs/g } \\
\text { bodyweight }\end{array}$ & intravenous & $\begin{array}{l}\downarrow \text { collagen deposition in the lung } \\
\downarrow \mathrm{mRNA} \text { expression of } \mathrm{IL}-1 \mathrm{~b} \text { in the } \\
\text { lung } \\
\downarrow \text { protection against fibrosis(treatment } \\
\text { with HGF knockdown stem cell) } \\
\downarrow \text { epithelial apoptosis in the lung }\end{array}$ \\
\hline $\begin{array}{l}\text { (Maria et al. } \\
\text { 2016a) }\end{array}$ & $\begin{array}{l}\mathrm{HOCl} \text { intradermic } \\
\text { injection/mouse } \\
\text { (daily, } 42 \text { days) }\end{array}$ & $\begin{array}{l}2.5 \times 10^{5} \text { (the most efficient } \\
\text { dose), } 5^{*} 10^{5} \text {, or } 10^{6} \text { syngeneic } \\
\text { BM-MSCs }\end{array}$ & intravenous & $\begin{array}{l}\downarrow \text { skin thickness } \\
\downarrow \text { total collagen content in the skin } \\
\downarrow \text { of COL } 1, \text { COL3, TGF } \beta 1 \text {, and a-SMA in } \\
\text { skin } \\
\downarrow \text { Col3 and TGF } \beta 1 \text { in the lung(in a } \\
\text { single dose injection on day } 21 \text { ) } \\
\downarrow \text { deposition of collagen in lung } \\
\downarrow \text { less ECM deposition } \\
\downarrow \text { cellular infiltration } \\
\downarrow \text { serum AOPP production } \\
\uparrow \text { serum antioxidant capacity } \\
\downarrow \text { anti-Scl-70 antibody serum levels }\end{array}$ \\
\hline
\end{tabular}

SCl-cGVHD Sclerodermatous chronic Graft Versus Host Disease, COL1A2 Collagen type I alpha 2 chain, miR Micro RNA, CAV-1 Caveolin-1, OSM Oncostatin M, BAL Bronchoalveolar lavage, Trx-1 Thioredoxin 1, FSP-1 Fibroblast-specific protein 1, HMGA High mobility group A, sRANKL Soluble Receptor Activator of Nuclear Factor, CFU-F Colony-Forming Unit-Fibroblastic, OCN Osteocalcin, ALP Alkaline phosphatase, Runx2 Runt-related transcription factor 2, LPL Lipoprotein Lipase, PPARY Peroxisome Proliferator-Activated Receptor $\gamma$, TIMP1 Tissue Inhibitor of Metalloproteinase 1, MMP Matrix Metalloproteinases, a-SMA Alpha-Smooth Muscle Actin, AD Adipose, TNF-a Tumour Necrosis Factor Alpha, HGF Hepatocyte Growth Factor, BM Bone Marrow, IL Interleukin, HOCI Hypochlorous Acid, MSC Mesenchymal Stem Cell, COL Collagen, TGF $\beta$ Transforming Growth Factor beta, ECM Extracellular Matrix, AOPP Advanced Oxidation Protein Products, NC No Change

matrix deposition) to the genome. This type has demonstrated to be valuable for investigating fibrosis and vasculopathy. Nevertheless, since SSc is not hereditary in humans, the mutations existing in this type cannot be applied to humans.

2. Transgenic models of fibrosis, which are momentous to recognize the part of particular genes related to fibrosis.

3. Knockout models of fibrosis that analyze the specific participation of a gene in fibrosis.

\section{Inducible animal models}

Several animal models are categorized as inducible ones (Asano and Sato 2013; Morin et al. 2015). Every model can mimic particular manifestations of the disease. To the date, mice and rats have been widely used as inducible animal models and are subdivided into several groups based on their target preclinical manifestations such as developing lung or skin fibrosis, mimicking inflammatory phases of the disease, pulmonary hypertension (Storkanova and Tomcik 2017) and presenting exact mechanisms induced by a particular factor. The HOCL-injected model is largely used in preclinical studies of scleroderma and exhibits systemic phenotype of human SSc through developing fibrosis, inflammation and vasculopathy as the main pathophysiological aspects of the disease (Asano and Sato 2013; Morin et al. 2015). A subgroup of models exclusively simulates the pattern of fibrosis extension in pulmonary tissue through fibroblast activation and increasing collagen gene expression (Storkanova and Tomcik 2017). Some models present skin fibrosis through the activation of micro-chimeric fetal cells (Storkanova and Tomcik 2017) and some simulate the inflammatory phases of SSc through 
Table 4 Some of MSC-based Clinical Data For Scleroderma

\begin{tabular}{|c|c|c|c|c|c|c|}
\hline $\begin{array}{l}\text { Source } \\
\text { of cells } \\
\text { or } \\
\text { tissues } \\
\end{array}$ & References & $\begin{array}{l}\text { Type of the } \\
\text { study }\end{array}$ & $\begin{array}{l}\text { The site of stem cell } \\
\text { injection }\end{array}$ & Included patients & Clinical outcomes & $\begin{array}{l}\text { Post-intervention } \\
\text { complications }\end{array}$ \\
\hline \multirow[t]{2}{*}{$\begin{array}{l}\text { Fat } \\
\text { tissue } \\
\text { auto } \\
\text { graft } \pm \\
\text { PRP }\end{array}$} & $\begin{array}{l}\text { (Daumas } \\
\text { et al. 2020) }\end{array}$ & Case report & $\begin{array}{l}\text {-PRP/microfat in nasolabial } \\
\text { folds and chin and } \\
\text { cheekbones } \\
\text {-PRP/emulsified fat in upper } \\
\text { lip, lower lip, and } \\
\text { submucosally at the level of } \\
\text { the oral commissure }\end{array}$ & $\begin{array}{l}1 \text { patient Affected by } \\
\text { systemic sclerosis- } \\
\text { related perioral } \\
\text { thickening }\end{array}$ & $\uparrow$ skin trophicity & $\begin{array}{l}\text {-minimal Bruising, pain and } \\
\text { swelling in donor areas } \\
\text {-superficial hematomas in the } \\
\text { injection site }\end{array}$ \\
\hline & $\begin{array}{l}\text { (Del Papa } \\
\text { et al. 2019) }\end{array}$ & Clinical trial & the base of the finger & $\begin{array}{l}\text { 25/13 patients with } \\
\text { IDU(fat/control } \\
\text { groups) }\end{array}$ & $\begin{array}{l}\uparrow I D U \text { healing } \\
\downarrow \text { pain } \\
\uparrow \text { the number of } \\
\text { capillaries in the } \\
\text { affected digit }\end{array}$ & NR \\
\hline $\begin{array}{l}\text { Fat } \\
\text { tissue } \\
\text { auto } \\
\text { graft/ } \\
\text { AD- } \\
\text { MSC }\end{array}$ & $\begin{array}{l}\text { (Onesti } \\
\text { et al. 2016) }\end{array}$ & Clinical trial & $\begin{array}{l}\text { Subcutaneous peri-oral } \\
\text { location }\end{array}$ & $\begin{array}{l}\text { 5/5 affected by dcSSc } \\
\text { (fat/ AD-MSC groups) }\end{array}$ & $\begin{array}{l}\uparrow \text { subjective wellness } \\
\text { of the skin in the } \\
\text { perioral areas } \\
\uparrow \text { IVMHISS score } \\
\uparrow \text { mouth opening } \\
\uparrow V A S \text { score } \\
\text { *the results were not } \\
\text { significantly different } \\
\text { between two groups }\end{array}$ & NR \\
\hline $\begin{array}{l}\text { AD- } \\
\text { MSC }\end{array}$ & $\begin{array}{l}\text { (Khanna } \\
\text { et al. 2018) }\end{array}$ & Clinical trial & Subcutaneous in all fingers & $\begin{array}{l}\text { 48/40With } \\
\text { impairment of hand } \\
\text { function(diffuse and } \\
\text { limited sclerosis } \\
\text { cases)(AD-MSC / } \\
\text { control groups) }\end{array}$ & $\begin{array}{l}\uparrow C H F S \text { score } \\
\downarrow R C S \\
\uparrow S H A Q \text { score } \\
\text { Improvement in EQ- } \\
5 D-5 L \text { assessment(- } \\
\text { diffuse subjects) } \\
\uparrow \text { Patient Global } \\
\text { Assessment of SSC } \\
\text { activity(diffuse } \\
\text { subjects) }\end{array}$ & $\begin{array}{l}\text {-Upper respiratory tract } \\
\text { infection } \\
\text {-Arthralgia } \\
\text {-Cellulitis } \\
\text {-Pain in extremity } \\
\text {-Hypoesthesia } \\
\text { The process is reported to be } \\
\text { safe }\end{array}$ \\
\hline \multirow[t]{3}{*}{$\begin{array}{l}\text { ADSVF } \\
\pm \text { PRP }\end{array}$} & $\begin{array}{l}\text { (Virzì et al. } \\
\text { 2017) }\end{array}$ & Case report & $\begin{array}{l}\text { Subcutaneous in peri-oral and } \\
\text { malar area }\end{array}$ & $\begin{array}{l}6 \text { patients affected } \\
\text { by dcSSc }\end{array}$ & $\begin{array}{l}\uparrow s k i n \text { elasticity } \\
\text { (improvement of the } \\
\text { opening and } \\
\text { extension } \\
\text { benchmarks of the } \\
\text { labial rhyme) } \\
\downarrow \text { longitudinal skin } \\
\text { wrinkles of the upper } \\
\text { lip more } \\
\text { harmonious, less } \\
\text { tense, } \uparrow \text { capillary } \\
\text { density } \\
\downarrow \text { vascular ectasia } \\
\uparrow \text { neoangiogenesis }\end{array}$ & NR \\
\hline & $\begin{array}{l}\text { (Song et al. } \\
\text { 2017) }\end{array}$ & Case report & $\begin{array}{l}\text { Subcutaneous in } \\
\text { metacarpophalangeal of both } \\
\text { hands and the amputation } \\
\text { stump of the left middle } \\
\text { finger, and under a skin } \\
\text { necrosis in the right hand. }\end{array}$ & $\begin{array}{l}62 \text { patients affected } \\
\text { by dcSSc }\end{array}$ & $\begin{array}{l}\text { There was no need } \\
\text { to further } \\
\text { amputation because } \\
\text { of gangrene, ulcer } \\
\text { and impaired wound } \\
\text { healing. }\end{array}$ & NR \\
\hline & $\begin{array}{l}\text { (Daumas } \\
\text { et al. 2017) }\end{array}$ & Clinical trial & All fingers & $\begin{array}{l}12 \text { patients with } \\
\text { hand disability of at } \\
\text { least } 20 \text { points using } \\
\text { CHFS. }\end{array}$ & $\begin{array}{l}\uparrow S H A Q \text { score } \\
\uparrow C H F S \text { score } \\
\uparrow g r i p \text { strength } \\
\uparrow \text { pinch strength } \\
\downarrow R C S \\
\downarrow D U \\
\text { NC in Mean global } \\
\text { disease severity score }\end{array}$ & NR \\
\hline $\begin{array}{l}\text { UC- } \\
\text { MSC }\end{array}$ & $\begin{array}{l}\text { (Zhang } \\
\text { et al. 2017) }\end{array}$ & Clinical trial & NR & $\begin{array}{l}14 \text { patients affected } \\
\text { by dcSSc }\end{array}$ & $\begin{array}{l}\downarrow \text { skin thickness } \\
\text { 个lung function (in } 3\end{array}$ & $\begin{array}{l}\text {-upper respiratory tract } \\
\text { infections -diarrhea }\end{array}$ \\
\hline
\end{tabular}


immune cell infiltration (Morin et al. 2015; Storkanova and Tomcik 2017; Yamamoto 2010). Several models are designed for pulmonary hypertension studies and the others develop particular processes induced by related factors; for example, the role of anti-topoisomerase immunization, TGF $\beta$, anti-endothelin I receptor type-A and anti-angiotensin II receptor type -1 antibodies in developing the pathological phenotype can be studied in particular models (Storkanova and Tomcik 2017). Therein, several preclinical models and their different features in addition to advantages and disadvantages are provided in detail in Table 2.

\section{Animal studies for mesenchymal stem cells - based treatments in scleroderma}

In order to have a better overview on the effects of MSC treatment on SSc phenotype, preclinical data from animal studies with a publication date from 2016 till now is reviewed. Bleomycin-induced, $\mathrm{HOCl}$-injected and Tsk1/+ models are three most commonly used animal models in this case. Moreover, among different types of mesenchymal stem cells, there has been a favored toward using BM-MSC in SSc animal experiments. Studies have shown that AD-MSC injection in SSc models counteracts fibrosis expansion in the lung and skin as well as levels of cytokines and gene products involved in fibrosis forming (Okamura et al. 2020; Rubio et al. 2018; Maria et al. 2016b). A better state of wound healing and lower levels of inflammation were also observed in the implicated sites (Rubio et al. 2018; Maria et al. 2016b). The same effects were reported from BM-MSC based experiments (Maria et al. 2016a; Maria et al. 2016b; Lan et al. 2017; Maria et al. 2018) as well as proposing the beneficial effect of HGF in causing BM-MSC to function more efficiently against fibrosis expansion (Cahill et al. 2016). In addition, some studies have reported the potential of thioredoxin 1 (Trx-1) overexpressing BM-MSC in lowering the apoptosis rate (Jiang et al. 2017). BM-MSC injection also decreases osteopenia and bone marrow substitution by adipose tissue in Tsk1/+ SSc models (Chen et al. 2017b). The inhibition of mammalian target of rapamycin (mTOR) pathway has been suggested as the underlying mechanism (Chen et al. 2017b). Beneficial effects of MSCbased therapeutic approaches on animal models of SSc have been provided in more detail in Table 3.

\section{Clinical studies on mesenchymal stem cells-based treatments for scleroderma subjects}

Clinical experiments of MSC-based treatments of SSc are provided in two categories of case reports and clinical trials. AD-MSC, UC-MSC, adipose tissue-derived stromal vascular fraction (ADSVF) and autologous fat are cells/tissues used in the studies we reviewed in order to counteract SSc symptoms. In some cases, regenerative materials have been utilized in combination with platelet-rich plasma (PRP). The reason for adding PRP is its nutritious plasma component that increases the survival of fat graft as well as improving the proliferation of pre-adipocytes through the secretion of particular types of growth factors and cytokines (Daumas et al. 2020). Studies have shown that fat tissue transplantation causes increased skin trophicity leading to better states of mouth opening and digital ulcer healing (Daumas et al. 2020; Del Papa et al. 2019; Onesti et al. 2016). An increased number of capillaries in affected sites were also reported in fat transplantation studies (Del Papa et al. 2019). The beneficial properties of fat tissue that make it suitable for cases affected by skin sclerosis are its biocompatibility, filling property and regenerative potential (due to its high content of multipotent stem or progenitor cells) (Rozier et al. 2018). AD-MSC injection has the same effect on mouth opening range as well as improving hand function and decreasing Raynaud's sign when applied subcutaneously to all fingers (Onesti et al. 2016; Khanna et al. 2018). ADSVF-based treatments show similar outcomes in enhancing angiogenesis and wound healing causing better hand function and preventing amputation due to hand gangrene (Song et al. 2017; Daumas et al. 2017; Virzì et al. 2017). Other studies have discussed the therapeutic function of UC-MSC in elevating hand and lung function as well as reducing collagen content in the skin in SSc patients (Liang et al. 2018; Wehbe et al. 2016; Zhang et al. 2017). The clinical results and experimental conditions of clinical studies with a publication date of 2016 till now are provided in more detail in Table 4.

\section{The most suitable type of mesenchymal stem cells for using in clinical trials of scleroderma}

As mentioned, several investigations have been established the advantageous impact of the autologous or allogeneic BM-MSCs and AD-MSCs in different SSc preclinical and clinical cases. Moreover, some of the studies were also evaluated the effects of UC-MSCs (Rozier et al. 2018; Cras et al. 2015). On the other hand, based on some reports, although whole MSCs revealed similar surface markers, various MSC populations from different tissues exhibited varied genetic profiles, and following that they can secrete different factors which can lead to various therapeutic features (Pittenger et al. 2019; Wegmeyer et al. 2013; Marquez-Curtis et al. 2015). In general, the most suitable type of MSC for therapeutic application is the one that can be easily isolated and extracted with less invasive methods. In addition, it can demonstrate its basilar capabilities in higher strength compared to its counterparts from other sources. Accordingly, in contrast to the BM and AD-MSCs, UC-MSCs can be 
Table 4 Some of MSC-based Clinical Data For Scleroderma (Continued)

\begin{tabular}{|c|c|c|c|c|c|c|}
\hline $\begin{array}{l}\text { Source } \\
\text { of cells } \\
\text { or } \\
\text { tissues } \\
\end{array}$ & References & $\begin{array}{l}\text { Type of the } \\
\text { study }\end{array}$ & $\begin{array}{l}\text { The site of stem cell } \\
\text { injection }\end{array}$ & Included patients & Clinical outcomes & $\begin{array}{l}\text { Post-intervention } \\
\text { complications }\end{array}$ \\
\hline & & & & & $\begin{array}{l}\text { ILD affected patients) } \\
\uparrow \text { ulcer healing } \\
\downarrow \text { Serum anti-Scl70 } \\
\text { autoantibody titer } \\
\downarrow T G F \beta \text { and VEGF } \\
\text { levels } \\
\text { NC in IFN- } \gamma, \text { IL-4 or } \\
\text { IL-10 }\end{array}$ & \\
\hline & $\begin{array}{l}\text { (Liang et al. } \\
\text { 2018) }\end{array}$ & $\begin{array}{l}\text { Retrospective } \\
\text { cohort }\end{array}$ & NR & $\begin{array}{l}39 \text { patients affected } \\
\text { by SSC }\end{array}$ & $\begin{array}{l}\text { mesenchymal stem } \\
\text { cell infusion is a safe } \\
\text { therapy for patients } \\
\text { with autoimmune } \\
\text { diseases }\end{array}$ & $\begin{array}{l}\text { The incidence of Hyper acute } \\
\text { (fever, headache, palpitation } \\
\text { and so on) and acute (hair } \\
\text { loss, facial rash and so on) } \\
\text { adverse effects, } \\
\text { transplantation-related mortal- } \\
\text { ity, infection and malignancy } \\
\text { are not high. Survival rate in1 } \\
\text { year after infusion is almost } \\
70 \%\end{array}$ \\
\hline & $\begin{array}{l}\text { (Wehbe } \\
\text { et al. 2016) }\end{array}$ & Case report & intravenous & $\begin{array}{l}2 \text { affected by } \\
\text { progressive, } \\
\text { refractory } \\
\text { scleroderma }\end{array}$ & $\begin{array}{l}\downarrow \text { dyspnea (first } \\
\text { subject) } \\
\text { Pulmonary } \\
\text { hypertension was } \\
\text { normalized (first } \\
\text { subject) } \\
\downarrow \text { skin contracture } \\
\text { (first subject) } \\
\text { pericardial effusion } \\
\text { was resolved (first } \\
\text { subject) } \\
\downarrow \text { joint pain (second } \\
\text { subject) } \\
\text { ability to exert was } \\
\text { normalized (second } \\
\text { subject) } \\
\downarrow \text { arthritis (second } \\
\text { subject) } \\
\downarrow \text { Raynaud's } \\
\text { phenomenon pain } \\
\text { (second subject) } \\
\uparrow m o b i l i t y \text { and } \\
\text { function(both } \\
\text { subjects after second } \\
\text { injection) }\end{array}$ & NR \\
\hline
\end{tabular}

PRP Platelet-Rich Plasma, IDU Indolent Digital Ulcers, IVMHISS Italian version of Mouth Handicap in Systemic Sclerosis Scale, VAS Visual Analogue Scale, AD Adipose, EQ-5D-5L EuroQol-5-Dimensions-5-Level, dcSSc Diffuse cutaneous Systemic Sclerosis, SSc Systemic Sclerosis, SHAQ Scleroderma Health Assessment Questionnaire, CHFS Cochin Hand Function Scale, RCS Raynaud's Condition Score, DU Digital Ulcer, ILD Interstitial Lung Disease, TGF $\beta$ Transforming Growth Factor beta, VEGF Vascular Endothelial Growth Factor, IL Interleukin, MSC Mesenchymal Stem Cell, NR Not Reported, NC No Change

achieved in larger numbers without an invasive method. Furthermore, they have a higher proliferation capacity than BM / AD-MSCs (El Omar et al. 2014). However, some other research has shown that UCMSC is less prone to adipogenic differentiation (Hematti and Keating 2013). While adipogenic differentiation ability can be helpful in order to attenuate some subcutaneous lesions in SSc individuals (Lee et al. 2017). Collectively, given that the majority of studies related to cell therapy in SSc patients are conducted with BM/AD MSCs, it seems that AD-MSCs are ideal candidates for cell-based treatments in SSc.
There are several reasons for this claim, including the following: 1 - they can be extracted more easily than BM- MSCs. 2- they have more proliferative, antifibrotic, and immunomodulatory potency compared to BM-MSCs (Scuderi et al. 2013; Del Papa et al. 2017). On the other hand, according to the bulk of studies accompanied on the choice between autologous and allogeneic MSC transplantation for the treatment of SSc subjects, cells derived from autologous sources are not appropriate due to alternations in some of the characteristics of MSCs in the microenvironmental conditions caused by scleroderma 
along with increasing their tendency to myofibroblastic differentiate and increase tissue fibrosis (Rozier et al. 2018; Peltzer et al. 2018).

\section{Conclusion and future perspectives}

The extent of the heterogeneity and severity of scleroderma, as well as the rate of progression in the skin and internal organs, are such that the common treatment options are not completely effective and only can help to alleviate a number of symptoms (Shah and Wigley 2013; Khanna 2011). Hereupon, the evaluation of more efficient approaches is demanded. Given the astonishing outcomes of cell-based therapies for different diseases (Goodarzi et al. 2018b; Rahim and Arjmand 2017; Baradaran-Rafii et al. 2020; Larijani et al. 2020; Arjmand et al. 2019), it isn't unlikely that cell therapies (specifically using MSCs) will also be effective for individuals with scleroderma. Indeed, MSCs as a practicing member of regenerative medicine with angiogenic, anti-fibrotic, antiinflammatory, and immunomodulatory functions, can affect the various disordering processes of the disease mainly via secreting specific efficient bioactive molecules (Han et al. 2019). In this context, finding out the most effective type of MSCs and of course, the best dose and method of administration can also shorten the distance to recovery through the MSCbased treatment. Herein, appropriate preclinical (in vitro and in vivo) studies for assessing the safety and efficacy of MSCs can be extremely valuable. Accordingly, based on the preclinical studies around the MSCs transplantation in SSc subjects and comparison of genetic profiles of employed MSCs, it seems that AD-MSCs especially those prepared from allogeneic sources can be considered as gold standard MSCs for clinical application. However, more extensive studies are still needed to find cells with the highest quality. Furthermore, examining the different cell culture conditions for a better cell function and using up-to-date techniques in this area can lead to more effective results. Herein, also increasing the information about the cellular and molecular mechanisms of disease can lead to several incredible advances in the diagnosis and treatment. On the other hand, the advanced omics technology (including genomics, transcriptomics, proteomics, and metabolomics) can be applied to recommend new hypotheses and understand particular underlying mechanisms of diseases (Larijani et al. 2019; Arjmand et al. 2017). Additionally, Knowledge-based computational disease modeling as a worthwhile tool that reduces using animal models, can create a fundamental mechanistic view of the disease. In general, the combination of these multidisciplinary advancements promises progress in recognizing the autoimmune disease and developing targeted therapies. On the other hand, the molecular phenotyping of SSc subjects can provide personalized medicine approaches to specific therapeutic interventions (Arjmand et al. 2017; Arjmand and Larijani 2017) which could raise the possibility of a positive treatment impact.

\section{Abbreviations}

SSc: Systemic Sclerosis; MSC: Mesenchymal Stem Cell; AOPPs: Advanced Oxidation Protein Products; HOCl: Hypochlorous Acid; CCR: CC chemokine receptor; NSIP: Nonspecific Interstitial Peumonitis; CAV-1: Caveolin-1; Th: T helper; IL: Interleukin; PKB: Protein Kinase B; HMGA: High mobility group A; SRANKL: soluble Receptor Activator of Nuclear Factor; CFU-F: Colony-Forming Unit-Fibroblastic; OCN: Osteocalcin; ALP: Alkaline phosphatase; Runx2: Runtrelated transcription factor 2; LPL: Lipoprotein Lipase; PPARY: Peroxisome Proliferator-Activated Receptor $\gamma$; RGS5: Regulator of G Protein Signaling 5; CFA: Complete Freund's Adjuvant; $\mathrm{ET}_{\mathrm{A}} \mathrm{R}$ : Anti-endothelin receptor Type-A; $\mathrm{AT}_{1} \mathrm{R}$ : Anti-angiotensin Receptor Type - 1; pSmad2: Phospho-Smad2; bFGF: Basic Fibroblast Growth Factor; CTGF: Connective Tissue Growth Factor; FITC: Fuorescein Isothiocyanate; TSP-1: Thrombospondin-1; BAL: Bronchoalveolar lavage; UIP: Usual Interstitial Pneumonia; RNP: Ribonucleoprotein; CCL: C-C Chemokine Ligand; ECM: Extracellular Matrix; Scl-GVHD: Sclerodermatous Graft Versus Host Disease; Scl-

CGVHD: Sclerodermatous chronic Graft Versus Host Disease; PAH: Pulmonary Atrial Hypertension; MCTP: Monocrotaline; SU5416: Semaxanib; BM: Bone Marrow; AD: Adipose; UC: Umbilical Cord; PL: Placenta; HLA-DR: Human Leukocyte Antigen-DR; EC: Endothelial Cell; TGFßRIl: TGF $\beta$ Receptor II; NGFR: Nerve Growth Factor Receptor; NGF: Nerve Growth Factor; EGF: Epidermal growth factor; ROS: Reactive Oxygen Species; Tsk1/+: Tight skin 1; a-SMA: Alpha-Smooth Muscle Actin; NG2: Neuron-Glial Antigen 2; SA$\beta G a l:$ Senescence-Associated $\beta$-Galactosidase; SDF-1: Stromal Derived Factor1; CXCR4: C-X-C chemokine receptor; HGF: Hepatocyte Growth Factor; TrX-

1: Thioredoxin 1; FSP-1: Fibroblast-specific protein 1; mTOR: Mammalian Target Of Rapamycin; miR: Micro RNA; IDU: Indolent Digital Ulcers;

DU: Digital Ulcer; PRP: Platelet-Rich Plasma; ADSVF: Adipose Tissue-Derived Stromal Vascular Fraction; dcSSc: Diffuse cutaneous Systemic Sclerosis; ILD: Interstitial Lung Disease; CHFS: Cochin Hand Function Scale; ADRC: Adipose Derived Regenerative Cell; RCS: Raynaud's Condition Score; SHAQ: Scleroderma Health Assessment Questionnaire; IVMHISS: Italian version of Mouth Handicap in Systemic Sclerosis Scale; VAS: Visual Analogue Scale; NC: No Change; NR: Not Reported; ND: No Data; PDGFb- R: Platelet-Derived Growth Factor Receptors; TGF $\beta$ : Transforming Growth Factor beta; COL: Collagen; MMP: Matrix Metalloproteinases; TIMP1: Tissue Inhibitor of Metalloproteinase 1; VEGF: Vascular Endothelial Growth Factor; FGF: Fibroblast Growth Factor; IGF-1: Insulin-like Growth Factor-1; PDGF: Platelet-Derived Growth Factor; PGE-2: Prostaglandin $E_{2}$ i IFNY: Interferon-Gamma; TNF-a: Tumour Necrosis Factor Alpha;

GILZ: Glucocorticoid-Induced Leucine Zipper; IDO: Indolamine-2,3dioxygenase; iNOS: Inducible NO Synthase; TSG-6: TNF-a-stimulated Gene-6; IL-1RA: Interleukin-1 Receptor Antagonist; HO-1: Heme Oxygenase-1; TNFR: TNF Receptor; GFP: Green Fluorescent; VEGFR: Vascular Endothelial Growth Factor Receptor; vWF: von Willebrand Factor; SOD: Superoxide Dismutase; PBS: Phosphate-Buffered Saline; OSM: Oncostatin M; EQ-5D5L: EuroQol-5-Dimensions-5-Level

\section{Authors' contributions}

Mina Abedi and Sepideh Alavi-Moghadam wrote the first draft. Parisa Goodarzi and Fereshteh Mohamadi-jahani helped to study and gather information, Moloud Payab and Forough Azam Sayahpour extensively edited the manuscript. Bagher Larijani participated in a critical review. Babak Arjmand helped supervise the project and gave final approval of the version to be published. The author(s) read and approved the final manuscript.

\section{Funding}

This article received no specific grant from any funding agency. 


\section{Author details}

${ }^{1}$ Cell Therapy and Regenerative Medicine Research Center, Endocrinology and Metabolism Molecular-Cellular Sciences Institute, Tehran University of Medical Sciences, Tehran, Iran. ${ }^{2}$ Metabolomics and Genomics Research Center, Endocrinology and Metabolism Molecular-Cellular Sciences Institute, Tehran University of Medical Sciences, Tehran, Iran. ${ }^{3}$ Brain and Spinal Cord Injury Research Center, Neuroscience Institute, Tehran University of Medical Sciences, Tehran, Iran. ${ }^{4}$ Department of Stem Cells and Developmental Biology, Cell Science Research Center, Royan Institute for Stem Cell Biology and Technology, ACECR, Tehran, Iran. ${ }^{5}$ Endocrinology and Metabolism Research Center, Endocrinology and Metabolism Clinical Sciences Institute, Tehran University of Medical sciences, Tehran, Iran.

Received: 2 June 2020 Accepted: 3 September 2020

Published online: 01 December 2020

\section{References}

Abbasi-Malati Z, Roushandeh AM, Kuwahara Y, Roudkenar MH. Mesenchymal stem cells on horizon: a new arsenal of therapeutic agents. Stem Cell Rev Rep. 2018;14(4):484-99.

Adnan ZA. Diagnosis and treatment of scleroderma. Acta Med Indones. 2008; 40(2):109-12.

Akiyama K, Chen C, Wang D, Xu X, Qu C, Yamaza T, et al. Mesenchymal-stem-cellinduced immunoregulation involves FAS-ligand-/FAS-mediated T cell apoptosis. Cell Stem Cell. 2012;10(5):544-55.

Arjmand B, Abdollahi M, Larijani B. Precision medicine: a new revolution in healthcare system. Iran Biomed J. 2017;21(5):282-3.

Arjmand B, Goodarzi P, Aghayan H, Payab M, Rahim F, Alavi-Moghadam S, et al. Co-transplantation of human fetal Mesenchymal and hematopoietic stem cells in type 1 diabetic mice model. Front Endocrinol. 2019;10:761.

Arjmand B, Larijani B. Personalized medicine: a new era in endocrinology. Acta Medica Iranica. 2017:55:142-3.

Artlett CM. Animal models of systemic sclerosis: their utility and limitations. Open Access Rheumatol. 2014;6:65.

Asano Y. Systemic sclerosis. J Dermatol. 2018;45(2):128-38.

Asano Y, Sato S. Animal models of scleroderma: current state and recent development. Curr Rheumatol Rep. 2013;15(12):382.

Baradaran-Rafii A, Sarvari M, Alavi-Moghadam S, Payab M, Goodarzi P, Aghayan $\mathrm{HR}$, et al. Cell-based approaches towards treating age-related macular degeneration. Cell Tissue Bank. 2020;21(3):339-47.

Becker MO, Kill A, Kutsche M, Guenther J, Rose A, Tabeling C, et al. Vascular receptor autoantibodies in pulmonary arterial hypertension associated with systemic sclerosis. Am J Respir Crit Care Med. 2014 190(7):808-17.

Bissell L-A, Anderson M, Burgess M, Chakravarty K, Coghlan G, Dumitru RB, et al. Consensus best practice pathway of the UK systemic sclerosis study group: management of cardiac disease in systemic sclerosis. Rheumatology. 2017; 56(6):912-21.

Bowen T, Jenkins RH, Fraser DJ. MicroRNAs, transforming growth factor beta-1, and tissue fibrosis. J Pathol. 2013;229(2):274-85.

Burt RK, Farge D. Autologous HSCT is efficacious, but can we make it safer? Nat Rev Rheumatol. 2018;14(4):189-91.

Cahill EF, Kennelly H, Carty F, Mahon BP, English K. Hepatocyte growth factor is required for mesenchymal stromal cell protection against bleomycin-induced pulmonary fibrosis. Stem Cells Transl Med. 2016;5(10):1307-18.

Cai X, Lin Y, Friedrich CC, Neville C, Pomerantseva I, Sundback CA, et al. Bone marrow derived pluripotent cells are pericytes which contribute to vascularization. Stem Cell Rev Rep. 2009;5(4):437-45.

Cardenas CLL, Henaoui IS, Courcot E, Roderburg C, Cauffiez C, Aubert S, et al. miR-199a-5p Is upregulated during fibrogenic response to tissue injury and mediates TGFbeta-induced lung fibroblast activation by targeting caveolin-1. PLoS Genet. 2013;9(2):e1003291.

Castello-Cros R, Whitaker-Menezes D, Molchansky A, Purkins G, Soslowsky LJ, Beason DP, et al. Scleroderma-like properties of skin from caveolin-1-deficient mice: implications for new treatment strategies in patients with fibrosis and systemic sclerosis. Cell Cycle. 2011;10(13):2140-50.

Chan YC, Roy S, Huang Y, Khanna S, Sen CK. The microRNA miR-199a-5p downregulation switches on wound angiogenesis by derepressing the $v$-ets erythroblastosis virus E26 oncogene homolog 1-matrix metalloproteinase-1 pathway. J Biol Chem. 2012;287(49):41032-43.
Chen C, Wang D, Moshaverinia A, Liu D, Kou X, Yu W, et al. Mesenchymal stem cell transplantation in tight-skin mice identifies miR-151-5p as a therapeutic target for systemic sclerosis. Cell Res. 2017b;27(4):559-77.

Chen W, Xia ZK, Zhang MH, Ding GC, Zhang XY, Wang ZX, et al. Adipose tissuederived stem cells ameliorates dermal fibrosis in a mouse model of scleroderma. Asian Pac J Trop Med. 2017a;10(1):52-6.

Chighizola C, Conrad K, Meroni PL. Systemic sclerosis. The General Practice Guide to Autoimmune Diseases; 2011. p. 15.

Chopra H, Hung M, Kwong D, Zhang C, Pow E. Insights into endothelial progenitor cells: origin, classification, potentials, and prospects. Stem Cells Int. 2018;2018:9847015

Christner PJ, Artlett CM, Conway RF, Jiménez SA. Increased numbers of microchimeric cells of fetal origin are associated with dermal fibrosis in mice following injection of vinyl chloride. Arthritis Rheumatism. 2000;43(11):2598-605.

Chung MP, Monick MM, Hamzeh NY, Butler NS, Powers LS, Hunninghake GW. Role of repeated lung injury and genetic background in bleomycin-induced fibrosis. Am J Respir Cell Mol Biol. 2003;29(3):375-80.

Cipriani P, Di Benedetto P, Liakouli V, Del Papa B, Di Padova M, Di lanni M, et al. Mesenchymal stem cells (MSC s) from scleroderma patients (SSC) preserve their immunomodulatory properties although senescent and normally induce T regulatory cells (Treg s) with a functional phenotype: implications for cellular-based therapy. Clin Exp Immunol. 2013a;173(2):195-206.

Cipriani P, Di Benedetto P, Ruscitti P, Campese AF, Liakouli V, Carubbi F, et al. Impaired endothelium-mesenchymal stem cells cross-talk in systemic sclerosis: a link between vascular and fibrotic features. Arthritis Res Ther. 2014; 16(5):442

Cipriani P, Marrelli A, Benedetto PD, Liakouli V, Carubbi F, Ruscitti P, et al. Scleroderma Mesenchymal stem cells display a different phenotype from healthy controls; implications for regenerative medicine. Angiogenesis. 2013b;16(3):595-607.

Cras A, Farge D, Carmoi T, Lataillade J-J, Wang DD, Sun L. Update on mesenchymal stem cell-based therapy in lupus and scleroderma. Arthritis Res Ther. 2015;17(1):301 Available from: http://europepmc.org/abstract/ MED/26525582, https://doi.org/10.1186/s13075-015-0819-7, https:// europepmc.org/articles/PMC4631077, https://europepmc.org/articles/ PMC4631077?pdf=render.

da Silva ML, Chagastelles PC, Nardi NB. Mesenchymal stem cells reside in virtually all post-natal organs and tissues. J Cell Sci. 2006;119(Pt 11):2204-13.

Daumas A, Magalon J, Delaunay F, Abellan M, Philandrianos C, Sabatier F, et al. Fat grafting for treatment of facial scleroderma. Clin Plast Surg. 2020;47(1): 155-63.

Daumas A, Magalon J, Jouve E, Truillet R, Casanova D, Giraudo L, et al. Long-term follow-up after autologous adipose-derived stromal vascular fraction injection into fingers in systemic sclerosis patients. Curr Res Transl Med. 2017; 65(1):40-3.

Dazzi F, van Laar JM, Cope A, Tyndall A. Cell therapy for autoimmune diseases. Arthritis research \& therapy. 2007;9(2):206.

Del Papa N, Di Luca G, Andracco R, Zaccara E, Maglione W, Pignataro F, et al. Regional grafting of autologous adipose tissue is effective in inducing prompt healing of indolent digital ulcers in patients with systemic sclerosis: results of a monocentric randomized controlled study. Arthritis Res Ther. 2019;21(1):1-11.

Del Papa N, Pignataro F, Zaccara E, Maglione W, Minniti A. Autologous hematopoietic stem cell transplantation for treatment of systemic sclerosis. Front Immunol. 2018:9:2390.

Del Papa N, Zaccara E, Di Luca G, Andracco R, Maglione W, Vitali C. Adiposederived cell transplantation in systemic sclerosis: state of the art and future perspectives. J Scleroderma Related Disord. 2017;2(1):33-41.

Desbois AC, Cacoub P. Systemic sclerosis: an update in 2016. Autoimmun Rev. 2016;15(5):417-26.

Dominici M, Le Blanc K, Mueller I, Slaper-Cortenbach I, Marini F, Krause D, et al. Minimal criteria for defining multipotent mesenchymal stromal cells. The International Society for Cellular Therapy position statement. Cytotherapy. 2006:8(4):315-7.

Duncan MR, Berman B. Differential regulation of collagen, glycosaminoglycan, fibronectin, and collagenase activity production in cultured human adult dermal fibroblasts by interleukin 1-alpha and beta and tumor necrosis factoralpha and beta. J Investig Dermatol. 1989;92(5):699-706.

El Omar R, Beroud J, Stoltz J-F, Menu P, Velot E, Decot V. Umbilical cord mesenchymal stem cells: the new gold standard for mesenchymal stem cellbased therapies? Tissue Eng B Rev. 2014;20(5):523-44. 
Elhai M, Meune C, Boubaya M, Avouac J, Hachulla E, Balbir-Gurman A, et al. Mapping and predicting mortality from systemic sclerosis. Ann Rheum Dis. 2017;76(11):1897-905.

Figueroa FE, Carrión F, Villanueva S, Khoury M. Mesenchymal stem cell treatment for autoimmune diseases: a critical review. Biol Res. 2012;45(3):269-77.

Goodarzi P, Aghayan HR, Larijani B, Soleimani M, Dehpour A-R, Sahebjam M, et al. Stem cell-based approach for the treatment of Parkinson's disease. Med J Islam Repub Iran. 2015;29:168

Goodarzi P, Aghayan HR, Soleimani M, Norouzi-Javidan A, Mohamadi-Jahani F, Jahangiri $S$, et al. Stem cell therapy for treatment of epilepsy. Acta Med Iran. 2014;52:651-5

Goodarzi P, Alavi-Moghadam S, Payab M, Larijani B, Rahim F, Gilany K, et al. Metabolomics analysis of mesenchymal stem cells. Int J Mol Cell Med. 2019a; 8(Suppl1):30

Goodarzi P, Alavi-Moghadam S, Sarvari M, Beik AT, Falahzadeh K, Aghayan H, et al. Adipose tissue-derived stromal cells for wound healing. Adv Exp Med Biol. 2018;1119:133-49.

Goodarzi P, Falahzadeh K, Aghayan H, Jahani FM, Payab M, Gilany K, et al. GMPcompliant human fetal skin fibroblasts for wound healing. Arch Neurosci. 2018b;5(3).

Goodarzi P, Payab M, Alavi-Moghadam S, Larijani B, Rahim F, Bana N, et al. Development and validation of Alzheimer's disease Animal model for the purpose of regenerative medicine. Cell Tissue Bank. 2019b;20(2):141-51.

Griffin M, Ryan CM, Pathan O, Abraham D, Denton CP, Butler PEM. Characteristics of human adipose derived stem cells in scleroderma in comparison to sex and age matched normal controls: implications for regenerative medicine. Stem Cell Res Ther. 2017;8(1):23 Available from: http://europepmc.org/ abstract/MED/28173869, https://doi.org/10.1186/s13287-016-0444-7, https:// europepmc.org/articles/PMC5297142, https://europepmc.org/articles/PMC52 97142?pdf=render

Guiducci S, Distler O, Distler J, Matucci-Cerinic M. Mechanisms of vascular damage in SSc_-implications for vascular treatment strategies. Rheumatology. 2008;47(suppl_5):v18-20.

Guiducci S, Manetti M, Romano E, Mazzanti B, Ceccarelli C, Dal Pozzo S, et al. Bone marrow-derived mesenchymal stem cells from early diffuse systemic sclerosis exhibit a paracrine machinery and stimulate angiogenesis in vitro. Ann Rheum Dis. 2011;70(11):2011-21.

Guimarães-Camboa N, Cattaneo P, Sun Y, Moore-Morris T, Gu Y, Dalton ND, et al. Pericytes of multiple organs do not behave as mesenchymal stem cells in vivo. Cell Stem Cell. 2017;20(3):345-59. e5.

Han Y, Li X, Zhang Y, Han Y, Chang F, Ding J. Mesenchymal stem cells for regenerative medicine. Cells. 2019;8(8):886.

Hasegawa M, Fujimoto M, Matsushita T, Hamaguchi Y, Takehara K, Sato S. Serum chemokine and cytokine levels as indicators of disease activity in patients with systemic sclerosis. Clin Rheumatol. 2011;30(2):231-7.

Hasegawa M, Sato S, Fujimoto M, Ihn H, Kikuchi K, Takehara K. Serum levels of interleukin 6 (IL-6), oncostatin M, soluble IL-6 receptor, and soluble gp130 in patients with systemic sclerosis. J Rheumatol. 1998;25(2):308-13.

Hematti P, Keating A. Mesenchymal stromal cells: biology and clinical applications: springer science \& business media; 2013.

Horikawa M, Hasegawa M, Komura K, Hayakawa I, Yanaba K, Matsushita T, et al. Abnormal natural killer cell function in systemic sclerosis: altered cytokine production and defective killing activity. J Investig Dermatol. 2005;125(4): $731-7$.

Huleihel L, Sellares J, Cardenes N, Álvarez D, Faner R, Sakamoto K, et al. Modified mesenchymal stem cells using miRNA transduction alter lung injury in a bleomycin model. Am J Phys Lung Cell Mol Phys. 2017;313(1):L92-L103.

Jiang M, Yu Y, Luo J, Gao Q, Zhang L, Wang Q, et al. Bone marrow-derived mesenchymal stem cells expressing thioredoxin 1 attenuate bleomycininduced skin fibrosis and oxidative stress in scleroderma. J Investig Dermatol. 2017;137(6):1223-33.

Jiang $Y$, Jahagirdar BN, Reinhardt RL, Schwartz RE, Keene CD, Ortiz-Gonzalez XR, et al. Pluripotency of mesenchymal stem cells derived from adult marrow. Nature. 2002:418(6893):41-9.

Jimenez SA, Christner PJ. Murine animal models of systemic sclerosis. Curr Opin Rheumatol. 2002;14(6):671-80.

Kern S, Eichler H, Stoeve J, Kluter H, Bieback K. Comparative analysis of mesenchymal stem cells from bone marrow, umbilical cord blood, or adipose tissue. Stem Cells. 2006;24(5):1294-301.

Keyser KA, Beagles KE, Kiem H-P. Comparison of mesenchymal stem cells from different tissues to suppress T-cell activation. Cell Transplant. 2007;16(5):555-62.
Khanna D. Diagnosis and treatment of systemic and localized scleroderma. Expert Rev Dermatol. 2011;6(3):287-302.

Khanna D, Caldron P, Martin R, Kafaja S, Spiera R, Shahouri S, et al. Adiposederived cell therapy for hand dysfunction in patients with systemic sclerosis: a randomized, double-blind, placebo-controlled trial. Age (years). 2018;54(9): $52-12$.

Kinnaird T, Stabile E, Burnett M, Shou M, Lee C, Barr S, et al. Local delivery of marrow-derived stromal cells augments collateral perfusion through paracrine mechanisms. Circulation. 2004;109(12):1543-9.

Krieg T, Takehara K. Skin disease: a cardinal feature of systemic sclerosis. Rheumatology. 2006;48(suppl_3):iii14-i8.

Krieg T, Takehara K. Skin disease: a cardinal feature of systemic sclerosis. Rheumatology. 2009;48(suppl_3):iii14-i8.

Lakos G, Takagawa S, Varga J. Animal models of scleroderma. Autoimmunity: Springer; 2004. p. 377-93.

Lalu MM, Mclntyre L, Pugliese C, Fergusson D, Winston BW, Marshall JC, et al. Safety of cell therapy with mesenchymal stromal cells (SafeCell): a systematic review and meta-analysis of clinical trials. PLoS One. 2012; 7(10):e47559.

Lan YW, Theng SM, Huang TT, Choo KB, Chen CM, Kuo HP, et al. Oncostatin Mpreconditioned mesenchymal stem cells alleviate bleomycin-induced pulmonary fibrosis through paracrine effects of the hepatocyte growth factor. Stem Cells Transl Med. 2017;6(3):1006-17.

Larghero J, Farge D, Braccini A, Lecourt S, Scherberich A, Fois E, et al. Phenotypical and functional characteristics of in vitro expanded bone marrow mesenchymal stem cells from patients with systemic sclerosis. Ann Rheum Dis. 2008;67(4):443-9.

Larijani B, Aghayan H, Goodarzi P, Mohamadi-Jahani F, Norouzi-Javidan A, Dehpour AR, et al. Clinical grade human adipose tissue-derived mesenchymal stem cell banking. Acta Med Iran. 2015:53(9):540-6.

Larijani B, Goodarzi P, Payab M, Alavi-Moghadam S, Rahim F, Bana N, et al. Metabolomics and cell therapy in diabetes mellitus. Int J Mol Cell Med (IJMCM). 2019;8(2):0.

Larijani B, Heravani NF, Alavi-Moghadam S, Goodarzi P, Rezaei-Tavirani M, Payab $\mathrm{M}$, et al. Cell therapy targets for autism spectrum disorders: hopes, challenges and future directions. 2020

Le Huu D, Matsushita T, Jin G, Hamaguchi Y, Hasegawa M, Takehara K, et al. IL-6 blockade attenuates the development of murine sclerodermatous chronic graft-versus-host disease. J Investig Dermatol. 2012;132(12):2752-61.

Lee R, Reese C, Carmen-Lopez G, Perry B, Bonner M, Zemskova M, et al. Deficient Adipogenesis of scleroderma patient and healthy African American monocytes. Front Pharmacol. 2017;8:174.

Lee SH, Lee EJ, Lee SY, Kim JH, Shim JJ, Shin C, et al. The effect of adipose stem cell therapy on pulmonary fibrosis induced by repetitive intratracheal bleomycin in mice. Exp Lung Res. 2014;40(3):117-25.

LeROY EC, Medsger TA Jr. Criteria for the classification of early systemic sclerosis. J Rheumatol. 2001:28(7):1573-6.

Liang J, Zhang H, Kong W, Deng W, Wang D, Feng X, et al. Safety analysis in patients with autoimmune disease receiving allogeneic mesenchymal stem cells infusion: a long-term retrospective study. Stem Cell Res Ther. 2018;9(1): $1-10$.

Lim JY, Ryu DB, Lee SE, Park G, Min CK. Mesenchymal stem cells (MSCs) attenuate cutaneous Sclerodermatous graft-versus-host disease (Scl-GVHD) through inhibition of immune cell infiltration in a mouse model. J Investigative Dermatol. 2017:137(9):1895-904.

Luz-Crawford P, Noël D, Fernandez X, Khoury M, Figueroa F, Carrión F, et al. Mesenchymal stem cells repress Th17 molecular program through the PD-1 pathway. PLoS One. 2012;7(9):e45272-e.

Maria AT, Maumus M, Le Quellec A, Jorgensen C, Noël D, Guilpain P. Adiposederived mesenchymal stem cells in autoimmune disorders: state of the art and perspectives for systemic sclerosis. Clin Rev Allergy Immunol. 2017;52(2): 234-59.

Maria AT, Toupet K, Bony C, Pirot N, Vozenin MC, Petit B, et al. Antifibrotic, antioxidant, and immunomodulatory effects of mesenchymal stem cells in HOCl-induced systemic sclerosis. Arthritis Rheumatol. 2016a;68(4):1013-25.

Maria AT, Toupet K, Maumus M, Fonteneau G, Le Quellec A, Jorgensen C, et al. Human adipose mesenchymal stem cells as potent anti-fibrosis therapy for systemic sclerosis. J Autoimmun. 2016b;70:31-9.

Maria ATJ, Toupet K, Maumus M, Rozier P, Vozenin M-C, Le Quellec A, et al. Fibrosis Development in $\mathrm{HOCl}$-Induced Systemic Sclerosis: A Multistage Process Hampered by Mesenchymal Stem Cells. Front Immunol. 2018;9:2571. 
Marquez-Curtis LA, Janowska-Wieczorek A, McGann LE, Elliott JA. Mesenchymal stromal cells derived from various tissues: biological, clinical and cryopreservation aspects. Cryobiology. 2015;71(2):181-97.

Matsushita T, Fujimoto M, Hasegawa M, Matsushita Y, Komura K, Ogawa F, et al. BAFF antagonist attenuates the development of skin fibrosis in tight-skin mice. J Investig Dermatol. 2007;127(12):2772-80.

Matsushita T, Hasegawa M, Hamaguchi Y, Takehara K, Sato S. Longitudinal analysis of serum cytokine concentrations in systemic sclerosis: association of interleukin 12 elevation with spontaneous regression of skin sclerosis. J Rheumatol. 2006;33(2):275-84.

Matsushita T, Kobayashi T, Mizumaki K, Kano M, Sawada T, Tennichi M, et al. BAFF inhibition attenuates fibrosis in scleroderma by modulating the regulatory and effector B cell balance. Sci Adv. 2018:4(7):eaas9944.

Maumus M, Jorgensen C, Noël D. Mesenchymal stem cells in regenerative medicine applied to rheumatic diseases: role of secretome and exosomes. Biochimie. 2013;95(12):2229-34.

Mayes MD. Scleroderma epidemiology. Rheum Dis Clin N Am. 2003;29(2):239-54.

Mercer PF, Woodcock HV, Eley JD, Platé M, Sulikowski MG, Durrenberger PF, et al. Exploration of a potent PI3 kinase/mTOR inhibitor as a novel anti-fibrotic agent in IPF. Thorax. 2016;71(8):701-11.

Morin F, Kavian N, Batteux F. Animal models of systemic sclerosis. Curr Pharm Des. 2015;21(18):2365-79.

Nicolls MR, Mizuno S, Taraseviciene-Stewart L, Farkas L, Drake Jl, Husseini AA, et al. New models of pulmonary hypertension based on VEGF receptor blockadeinduced endothelial cell apoptosis. Pulmonary Circulation. 2012;2(4):434-42.

Nikpour M, Stevens W, Herrick A, Proudman S. Epidemiology of systemic sclerosis. Best Pract Res Clin Rheumatol. 2010;24:857-69.

Okamura A, Matsushita T, Komuro A, Kobayashi T, Maeda S, Hamaguchi Y, et al. Adipose-derived stromal/stem cells successfully attenuate the fibrosis of scleroderma mouse models. Int J Rheum Dis. 2020;23(2):216-25.

Onesti MG, Fioramonti P, Carella S, Fino P, Marchese C, Scuderi N. Improvement of mouth functional disability in systemic sclerosis patients over one year in a trial of fat transplantation versus adipose-derived stromal cells. Stem Cells Int. 2016;2016:2416192.

Oswald J, Boxberger S, Jørgensen B, Feldmann S, Ehninger G, Bornhäuser M, et al. Mesenchymal stem cells can be differentiated into endothelial cells in vitro. Stem Cells. 2004;22(3):377-84.

Paduano F, Marrelli M, Amantea M, Rengo C, Rengo S, Goldberg M, et al. Adipose tissue as a strategic source of mesenchymal stem cells in bone regeneration: a topical review on the most promising craniomaxillofacial applications. Int J Mol Sci. 2017;18(10):2140.

Pattanaik D, Brown M, Postlethwaite BC, Postlethwaite AE. Pathogenesis of systemic sclerosis. Front Immunol. 2015;6:272

Payab M, Goodarzi P, Heravani NF, Hadavandkhani M, Zarei Z, Falahzadeh K, et al. Stem cell and obesity: current state and future perspective. Cell Biol Transl Med. 2018;2: Springer:1-22.

Peltzer J, Aletti M, Frescaline N, Busson E, Lataillade J-J, Martinaud C. Mesenchymal stromal cells based therapy in systemic sclerosis: rational and challenges. Front Immunol. 2018;9:2013.

Pittenger MF, Discher DE, Péault BM, Phinney DG, Hare JM, Caplan Al. Mesenchymal stem cell perspective: cell biology to clinical progress. NPJ Regenerative Med. 2019;4(1):1-15.

Poudel DR, Jayakumar D, Danve A, Sehra ST, Derk CT. Determinants of mortality in systemic sclerosis: a focused review. Rheumatol Int. 2018;38(10):1847-58.

Radbruch A, Thiel A. Cell therapy for autoimmune diseases: does it have a future? Ann Rheumatic Dis. 2004;63(suppl 2):ii96-ii101.

Rahim F, Arjmand B. Stem cell clinical trials for multiple sclerosis: the past, present and future. Neurological Regeneration: Springer; 2017. p. 159-72.

Resnick IB, Metodiev K, Lazarova P. Hematopoietic cell transplantation for autoimmune diseases: a review of history, current state, and future issues. Immunotherapy-Myths, Reality, Ideas, Future: IntechOpen; 2017.

Reyes M, Dudek A, Jahagirdar B, Koodie L, Marker PH, Verfaillie CM. Origin of endothelial progenitors in human postnatal bone marrow. J Clin Invest. 2002;109(3):337-46.

Rosa SB, Voltarelli JC, Chies JAB, Pranke P. The use of stem cells for the treatment of autoimmune diseases. Braz J Med Biol Res. 2007;40(12):1579-97.

Rozier P, Maria A, Goulabchand R, Jorgensen C, Guilpain P, Noël D. Mesenchymal stem cells in systemic sclerosis: allogenic or autologous approaches for therapeutic use? Front Immunol. 2018;9:2938.

Rubio GA, Elliot SJ, Wikramanayake TC, Xia X, Pereira-Simon S, Thaller SR, et al. Mesenchymal stromal cells prevent bleomycin-induced lung and skin fibrosis in aged mice and restore wound healing. J Cell Physiol. 2018;233(8):5503-12.
Ruiz M, Cosenza S, Maumus M, Jorgensen C, Noël D. Therapeutic application of mesenchymal stem cells in osteoarthritis. Expert Opin Biol Ther. 2016;16(1): 33-42.

Sapadin AN, Fleischmajer R. Treatment of scleroderma. Arch Dermatol. 2002: 138(1):99-105.

Scuderi N, Ceccarelli S, Onesti MG, Fioramonti P, Guidi C, Romano F, et al. Human adipose-derived stromal cells for cell-based therapies in the treatment of systemic sclerosis. Cell Transplant. 2013;22(5):779-95.

Shah AA, Wigley FM. My approach to the treatment of scleroderma. Mayo Clinic Proceedings; 2013: Elsevier.

Sobolewski P, Maślińska M, Wieczorek M, Łagun Z, Malewska A, Roszkiewicz M, et al. Systemic sclerosis-multidisciplinary disease: clinical features and treatment. Reumatologia. 2019a;57(4):221-31.

Sobolewski P, Maślińska M, Wieczorek M, Lagun Z, Malewska A, Roszkiewicz M, et al. Systemic sclerosis - multidisciplinary disease: clinical features and treatment. Reumatologia/Rheumatology. 2019b;57:221-33.

Soleimani M, Aghayan HR, Goodarzi P, Hagh MF, Lajimi AA, Saki N, et al. Stem cell therapy-approach for multiple sclerosis treatment. Arch Neurosci. 2016; 3(1):e21564.

Song J, Volz S, Liodaki M, Mailänder P, Kalousis K. Stem cells therapy: the future in the management of systemic sclerosis? A case report. Hell J Nucl Med. 2017; 20(Suppl):164.

Stenmark KR, Meyrick B, Galie N, Mooi WJ, McMurtry IF. Animal models of pulmonary arterial hypertension: the hope for etiological discovery and pharmacological cure. Am J Phys Lung Cell Mol Phys. 2009;297(6):L1013-L32.

Sticherling M. Systemic sclerosis-dermatological aspects. Part 1: pathogenesis, epidemiology, clinical findings. J Dtsch Dermatol Ges. 2012;10(10):705-16.

Storkanova H, Tomcik M. Animal models of systemic sclerosis. Systemic Sclerosis. 2017;181.

Sullivan KM, Goldmuntz EA, Keyes-Elstein L, McSweeney PA, Pinckney A, Welch B, et al. Myeloablative autologous stem-cell transplantation for severe scleroderma. N Engl J Med. 2018;378(1):35-47.

Tashiro J, Elliot SJ, Gerth DJ, Xia X, Pereira-Simon S, Choi R, et al. Therapeutic benefits of young, but not old, adipose-derived mesenchymal stem cells in a chronic mouse model of bleomycin-induced pulmonary fibrosis. Transl Res. 2015;166(6):554-67.

Toyoshima A, Yasuhara T. Mesenchymal stem cell therapy for ischemic stroke. Acta Med Okayama. 2017;71(4):263-8.

Uji M, Nakada A, Nakamura T, Hirata K. Effect of intratracheal administration of adipose-derived stromal cells on bleomycin-induced lung injury in a rat model. Osaka City Med J. 2015;61:81-91.

van Laar JM, Farge D, Sont JK, Naraghi K, Marjanovic Z, Larghero J, et al. Autologous hematopoietic stem cell transplantation vs intravenous pulse cyclophosphamide in diffuse cutaneous systemic sclerosis: a randomized clinical trial. Jama. 2014;311(24):2490-8.

van Laar JM, Sullivan K. Stem cell transplantation in systemic sclerosis. Curr Opin Rheumatol. 2013;25(6):719-25.

Velier M, Simoncini S, Abellan M, Francois P, Eap S, Lagrange A, et al. Adiposederived stem cells from systemic sclerosis patients maintain pro-Angiogenic and Antifibrotic paracrine effects in vitro. J Clin Med. 2019;8(11):1979.

Virzì F, Bianca P, Giammona A, Apuzzo T, Di Franco S, Mangiapane LR, et al. Combined platelet-rich plasma and lipofilling treatment provides great improvement in facial skin-induced lesion regeneration for scleroderma patients. Stem Cell Res Ther. 2017;8(1):236.

Wang B, Yao K, Huuskes BM, Shen $\mathrm{H}-\mathrm{H}$, Zhuang J, Godson C, et al. Mesenchymal stem cells deliver exogenous microRNA-let7c via exosomes to attenuate renal fibrosis. Mol Ther. 2016;24(7):1290-301.

Wegmeyer H, Bröske A-M, Leddin M, Kuentzer K, Nisslbeck AK, Hupfeld J, et al. Mesenchymal stromal cell characteristics vary depending on their origin. Stem Cells Dev. 2013;22(19):2606-18.

Wehbe T, Saab MA, Chahine NA, Margossian T. Mesenchymal stem cell therapy for refractory scleroderma: a report of 2 cases. Stem Cell Investigation. 2016;3:48.

Wei J, Bhattacharyya S, Tourtellotte WG, Varga J. Fibrosis in systemic sclerosis: emerging concepts and implications for targeted therapy. Autoimmun Rev. 2011;10(5):267-75.

Yamamoto T. Animal model of systemic sclerosis. J Dermatol. 2010;37(1):26-41.

Yamamoto T. Animal Models of Systemic Sclerosis. Animal Models for the Study of Human Disease: Elsevier; 2017. p. 951-66.

Yamamoto T, Takagawa S, Kuroda M, Nishioka K. Effect of interferon- $\gamma$ on experimental scleroderma induced by bleomycin. Arch Dermatol Res. 2000; 292(7):362-5 
Yoshizaki A, Yanaba K, Iwata Y, Komura K, Ogawa A, Akiyama Y, et al. Cell adhesion molecules regulate fibrotic process via Th1/Th2/Th17 cell balance in a bleomycin-induced scleroderma model. J Immunol. 2010;185(4):2502-15.

Yu H, Lu K, Zhu J. Wang Ja. Stem cell therapy for ischemic heart diseases. Br Med Bull. 2017;121(1):135-54.

Zakrzewski W, Dobrzyński M, Szymonowicz M, Rybak Z. Stem cells: past, present, and future. Stem Cell Res Ther. 2019;10(1):68.

Zeineddine N, Khoury LE, Mosak J. Systemic sclerosis and malignancy: a review of current data. J Clin Med Res. 2016;8(9):625-32.

Zhang $H$, Liang J, Tang $X$, Wang D, Feng $X$, Wang F, et al. Sustained benefit from combined plasmapheresis and allogeneic mesenchymal stem cells transplantation therapy in systemic sclerosis. Arthritis Res Ther. 2017;19(1):165. Zhang XL, Xing RG, Chen L, Liu CR, Miao ZG. PI3K/Akt signaling is involved in the pathogenesis of bleomycininduced pulmonary fibrosis via regulation of epithelialmesenchymal transition. Mol Med Rep. 2016:14(6):5699-706.

Zhao Q, Ren H, Han Z. Mesenchymal stem cells: Immunomodulatory capability and clinical potential in immune diseases. J Cell Immunother. 2016;2(1):3-20.

\section{Submit your manuscript to a SpringerOpen ${ }^{\circ}$ journal and benefit from:}

- Convenient online submission

- Rigorous peer review

- Open access: articles freely available online

High visibility within the field

- Retaining the copyright to your article

Submit your next manuscript at $\boldsymbol{\nabla}$ springeropen.com 